\title{
Investigations on the ecology of Calanus spp. in the Labrador Sea. I. Relationship between the phytoplankton bloom and reproduction and development of Calanus finmarchicus in spring
}

\author{
E. J. H. Head*, L. R. Harris, R. W. Campbell** \\ Department of Fisheries and Oceans, Ocean Sciences Division, Bedford Institute of Oceanograhy, PO Box 1006, Dartmouth, \\ Nova Scotia B2Y 4A2, Canada
}

\begin{abstract}
During mid-May-early June 1997 observations of hydrography, phytoplankton and nitrate concentrations, and abundance and stage distribution of Calanus finmarchicus populations were made in the Labrador Sea and south of Greenland. Egg production rates were also measured for isolated $C$. finmarchicus females. Surface nitrate and integrated phytoplankton concentrations indicated that, in the deep water, the phytoplankton bloom had ended in the north and east, was in progress in the north central Labrador Sea and near the basin margins, and had not yet become established in an area stretching from the central Labrador Sea to the south of Greenland. C. finmarchicus egg production rates and stage distributions at stations in the 3 areas designated as early, mid-and late/post-bloom zones, suggested that development rates of the overwintered G0 generation into mature adults (females and males) were probably low before the bloom, but accelerated during its development. Individual and areal rates of egg production were highest in the early bloom zone, whereas nauplii were more abundant in the bloom and late/post-bloom zones. Differences in naupliar abundance may have been related to food limitation, or predation. Following development through to the young copepodite stages (CI-III), which were most abundant in the late/post-bloom zone, morality rates were apparently lower and growth rates less dependent on high phytoplankton concentrations and perhaps more dependent on temperature. In the Labrador Sea, where the annual growth season is relatively short and $C$. finmarchicus produces only 1 generation per year, the timing of the spring bloom may have a significant impact on recruitment of the new year's generation. In areas where the bloom is early and intense, maturation of the overwintered adults will be rapid and egg-laying will occur when phytoplankton concentrations are high. Subsequent survival success of eggs through to later stages will also probably be relatively high and individuals from the new year's generation will have ample time to reach stages capable of overwintering. By contrast, if the bloom is late or of low intensity, adult maturation will be delayed and egg-laying may occur when phytoplankton concentrations are low. Under these conditions relatively few eggs may survive and individuals that do survive will have a shorter period in which to attain stages which can overwinter.
\end{abstract}

KEY WORDS: Calanus finmarchicus $\cdot$ Reproduction $\cdot$ Spring bloom $\cdot$ Labrador Sea

\section{INTRODUCTION}

Detailed studies of ecological and biological processes in the Labrador Sea have been relatively scarce, with the exceptions of the observations of Kielhorn

\footnotetext{
-E-mail: heade@mar.dfo-mpo.gc.ca

-Present address: Department of Earth and Ocean Sciences University of British Columbia, Vancouver, British Columbia V6T 1Z4, Canada
}

(1952) of the annual cycle of zooplankton abundance at Ocean Station Bravo $\left(56^{\circ} 30^{\prime} \mathrm{N}, 51^{\circ} 00^{\prime} \mathrm{W}\right)$, which included information on hydrography and phytoplankton abundance, and the reports of the ICNAF (International Commission for the Northwest Atlantic Fisheries) Norwestlant I-III surveys, which included observations of hydrography, phytoplankton and zooplankton distributions for 3 time periods between late March and July for sections across the Greenland Shelf and in the Irminger and Labrador Seas (ICNAF 1968). 


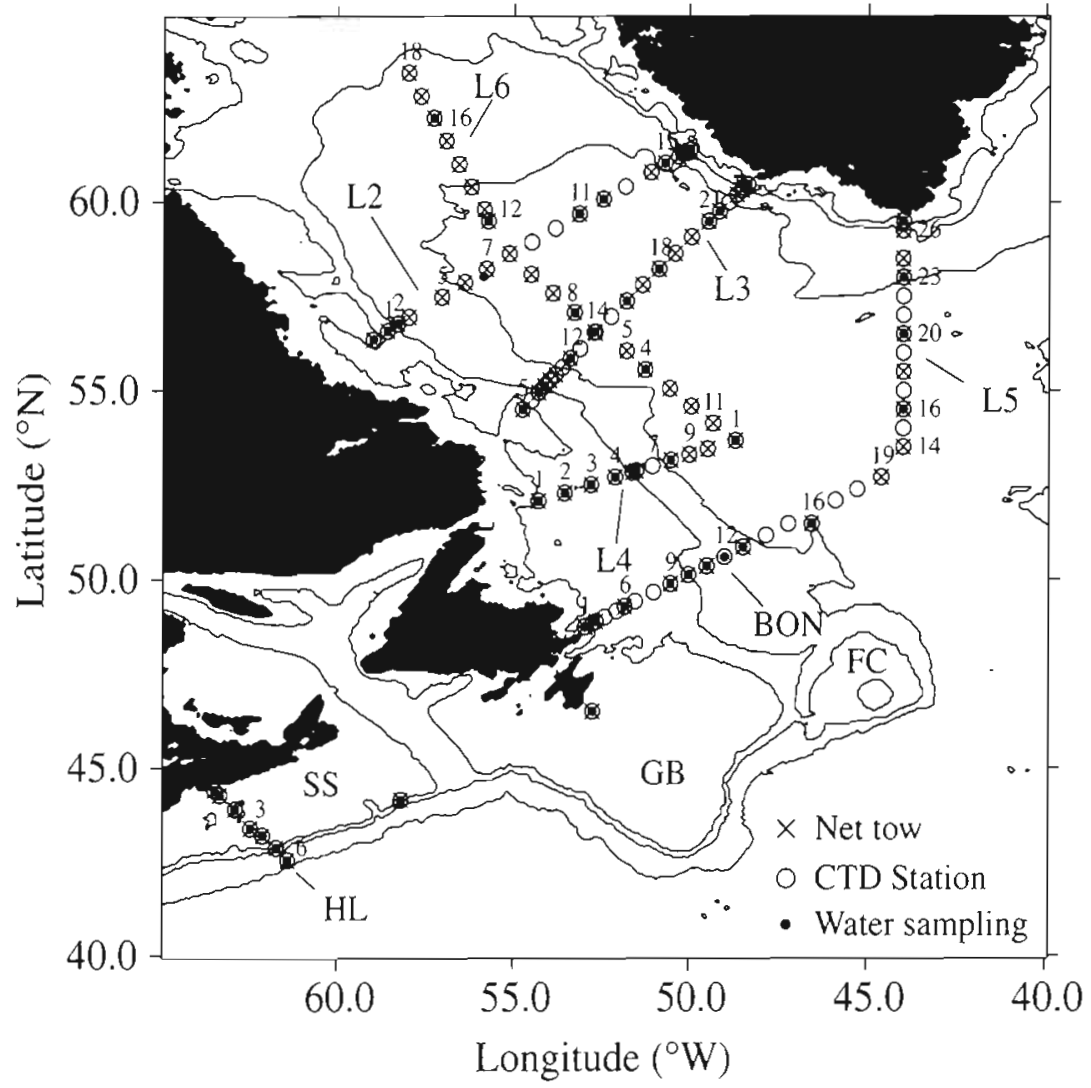

Fig. 1. Hydrographic and biological sampling stations occupied during MayJune 1997 BON: Cape Bonavista Line; FC: Flemish Cap; GB: Grand Bank; HL: Halifax Line; SS: Scotian Shelf; L2-L5: Lines 2 to 5.Contours are at 200, 1000 and $3000 \mathrm{~mm}$

Additional observations of the distribution of zooplankton abundance, over the entire Labrador Sea (Grainger 1963) or areas within it (Huntley et al. 1983), have also been reported. More recently, the Biological Oceanography group from the Bedford Institute of Oceanography has been extending previous observations in the Labrador Sea during a number of cruises: 3 in spring (May-June: 1994, 1996, 1997); 2 in summer (July: 1995, 1998); and 1 in autumn (Oct.: 1996). During each cruise sampling was carried out along the WOCE (World Ocean Circulation Experiment) AR7/W Section (Fig. 1, L3), which runs from Hamilton Bank (Labrador Shelf) to Cape Desolation (Greenland), and additional lines were run on some cruises. Sampling has generally included measurements of temperature, salinity and nutrient concentrations and observations of the distribution of phytoplankton, zooplankton and bacteria within the near-surface layers (0 to $100 \mathrm{~m}$ ).

Seasonal and interannual observations of hydrographic conditions and the distributions of phytoplankton and all zooplankton species will be described elsewhere (Head unpubl.), but here we will report on observations made during only one cruise, that of the spring of 1997, for which the spatial coverage was most extensive (Fig. 1). Furthermore, in this paper we confine our attention to 1 of the 3 Calanus species that dominate the zooplankton in the area, namely C. finmarchicus, and we will discuss the relationship of reproduction and recruitment in this species to the dynamics of the phytoplankton bloom. The reasons for limiting the discussion to $C$. finmarchicus are 2-fold: firstly, it is arguably the most important copepod in the Labrador Sea (in the central basin at least); and, secondly, this species and variations in its life history throughout its geographic range are subjects of prime interest for current international studies, including GLOBEC (Global Ocean Ecosystem Dynamics) and TASC (Trans Atlantic Study of Calanus).

Calanus finmarchicus is distributed throughout the Atlantic, from the New England Shelf $\left(40^{\circ} \mathrm{N}\right)$ in the southwest, to the Greenland and Barents Seas $\left(80^{\circ} \mathrm{N}\right.$ ) in the northeast (Planque et al. 1997) and populations in different areas vary with respect to certain life history characterisitics, such as the number of generations produced annually. In the west, on Georges

Bank (ca $42^{\circ} \mathrm{N}$ ), it appears that some portion of the $C$. finmarchicus population remains reproductively active throughout most of the year and that several generations may be produced annually (Durbin et al. 1997), while in the east, north of the Faroes (ca $64^{\circ} \mathrm{N}$ : Gaard 1996), in northern Norway (69 ${ }^{\circ}$ : Diel \& Tande 1992) and the Barents Sea (ca $74^{\circ} \mathrm{N}$ : Tande et al. 1985), C. finmarchicus apparently produces only 1 generation per year. Between these extremes, on the mid-and western regions of the Scotian Shelf (McLaren \& Corkett 1986, I. A. McLaren, E. Head, D. D. Sameoto unpubl.), in the waters around Iceland (Longhurst \& Williams 1992, Gislasson \& Astthorsson 1996, 1998) and east of the Faroes (Gaard 1996), there appear to be 2 generations per year, although the second may contribute little to the annual production (e.g. McLaren \& Corkett 1986, Gislasson \& Astthorson 1998). In the Labrador Sea, at Ocean Station Bravo, Kielhorn (1952) suggested that $C$. finmarchicus produces 2 generations per year. Using the Norwestlant survey data, Matthews (1968) suggested that there is 1 generation per year throughout our study area (Fig. 1). Our recent observations have also suggested that there is only 1 
generation produced per year throughout most of the Labrador Sea. Young copepodite stages of a second minor generation are sometimes seen, but it is possible that few of these develop to stages that can successfully overwinter by autumn (Grainger 1963, Head unpubl.).

The arousal from diapause and spring ascent of Calanus finmarchicus may be triggered by changes in photoperiod or some internal mechanism (Hirche 1996), but the initiation of reproduction seems to be linked to the start of the spring bloom. There is some controversy as to whether females start producing eggs before (e.g. Diel \& Tande 1992, Gislasson \& Astthorsson 1996) or only after (Runge \& Plourde 1996) the bloom has actually become established, but there is general agreement that sustained egg production requires that females feed (Marshall \& Orr 1952, Plourde \& Runge 1993, Hirche et al. 1997) and that egg production rates are generally maximal during the spring bloom (Anderson 1990, Diel \& Tande 1992, Gislasson \& Astthorson 1996). Rates may remain high even after the bloom has ended, however, if alternative food sources are available (Runge \& Plourde 1996). According to Matthews (1968), female C. finmarchicus throughout our sampling area start to breed in April and, from observations of eggs and nauplii in the water, Anderson (1990) suggested that the peak breeding season for $C$. finmarchicus on and around Flemish Cap (Fig. 1) was mid-April. During our 1997 cruise to the Labrador Sea, which was from mid-May to early June, egg production rates, measured for groups of individual C. finmarchicus females (Campbell 1998, Campbell \& Head 2000), were generally high. In fact, in the central Labrador Sea and south of Greenland (L5 line, Fig. 1) females had the highest rates ever observed for the species, for the relatively low ambient temperatures. In addition, since adults dominated the population at many stations, it is obvious that reproduction was still important in May and early June.

In this paper, we present data describing: the abundance and stage structure of Calanus finmarchicus populations; hydrography; nitrate and phytoplankton concentrations; and areal estimates of egg production rates, for the near surface layers (0 to $100 \mathrm{~m}$ ) at stations throughout the Labrador Sea, sampled between May 13 and June 9, 1997 (Fig. 1). On the basis of these observations we will attempt to: assess the state of the spring bloom in different areas of the study region; explore the relationship between reproduction in $C$. finmarchicus populations and the state of the spring bloom; and examine the survival success of the newly laid eggs throughout the region, in order to make some suggestions as to factors which might be contributing to egg and naupliar survival and recruitment in the species.

\section{MATERIALS AND METHODS}

The sampling operations carried out at each of the sampling stations during the 1997 spring cruise to the Labrador Sea are shown in Fig. 1. Hydrographic and biological sampling was along the Halifax Line (HL) on May 9 and 10; along the Bonavista (BON) and L5 lines between May 13 and 20; along the L3 (the WOCE AR/7 section) and L2 lines between May 21 and June 2; and along the L6 and L4 lines, between June 3 and 9 .

Hydrographic measurements and water sampling. Temperature and salinity profiles were collected throughout the full ocean depth using a Seabird (Model SBE 25) sensor mounted on a CTD rosette, or in the 0 to $100 \mathrm{~m}$ depth range using a Seabird (Model SBE 25) sensor mounted on the frame of a biological pump. Both the CTD rosette and the pump frame also carried submersible fluorometers (Chelsea Instruments Aquatracka 3 and Sea Tech Model 304, respectively). Water samples were collected by means of the pump (or occasionally from bottles on the CTD rosette) for the determination of extracted chlorophyll and nutrient concentrations at $10 \mathrm{~m}$ intervals in the 0 to $100 \mathrm{~m}$ depth range. For extracted chlorophyll determinations, water samples $(100 \mathrm{ml})$ were filtered through $\mathrm{GF} / \mathrm{F}$ filters, which were immediately placed in $90 \%$ acetone and stored at $-20^{\circ} \mathrm{C}$ until analysis, which was between 1 and $3 \mathrm{~d}$ after sample collection. Chlorophyll concentrations were measured using a Turner Designs fluorometer according to the method of Holm-Hansen et al. (1965). For the determination of nutrient concentrations, water samples were frozen at $-20^{\circ} \mathrm{C}$ and analysed back in the laboratory using an Alpkem RF-300 autoanalyser.

Continuous monitoring at $5 \mathbf{~ m}$. Temperature and salinity data were recorded continuously using Seabird sensors in the intake of the ship's 'clean' underway pumping system, which collected water ca $5 \mathrm{~m}$ depth. A Wetstar 3 (Wetlab) submersible fluorometer was used to monitor fluorescence. The fraction collector from an autoanalyser was used to collect water samples for the determination of nutrient concentrations from a small flow-through reservoir at $15 \mathrm{~min}$ intervals. These were frozen at $-20^{\circ} \mathrm{C}$ and analysed as described above. Two or 3 times per day, water samples were taken for the determination of extracted chlorophyll concentration (as described above) to calibrate the fluorometer.

Zooplankton sampling. Zooplankton were collected in vertical net hauls between 100 and $0 \mathrm{~m}$ using a $0.75 \mathrm{~m}$ diameter ring net fitted with a $200 \mu \mathrm{m}$ mesh The cod-end was attached to the weight on the bottom of the hydro-wire and the towing bridle, to a crossbow mounted on the wire at a height above the 
weight such that the net was held vertically. In this configuration zooplankton were only collected as the net was towed upwards. The towing speed was ca $0.5 \mathrm{~m} \mathrm{~s}^{-1}$ and the volume of water sampled was assumed to be the volume of the cylinder filterd by the net. Samples were preserved in $2 \%$ formalin. Size frequency distributions of sizes-at-stage were constructed at each station and were used to distinguish the early copepodite stages (CI-CII) of Calanus finmarchicus from those of C. glacialis. There was no size overlap in the later stages (CIII-CVI). Dry weights were determined for groups of individuals belonging to each stage of $C$. finmarchicus at each of the sampling stations. Biomass results (dry weights) based on these are presented without correction for formalin preservation.

\section{RESULTS}

\section{Near-surface temperature, salinity, nitrate concentrations and fluorescence from the continuous monitoring system}

Areal contour plots of near-surface temperature, salinity, nitrate and fluorescence at ca $5 \mathrm{~m}$ were compiled from data collected along the ship's track using the continuous monitoring system (Fig. 2). The absolute values of temperature and salinity (which must be corrected for temperature) were not precise, because the water warmed by 1 to $2^{\circ} \mathrm{C}$ as it passed through the system, but the spatial trends were real. Thus, areal contour plots of temperature and salinity showed features which are consistent with our under-

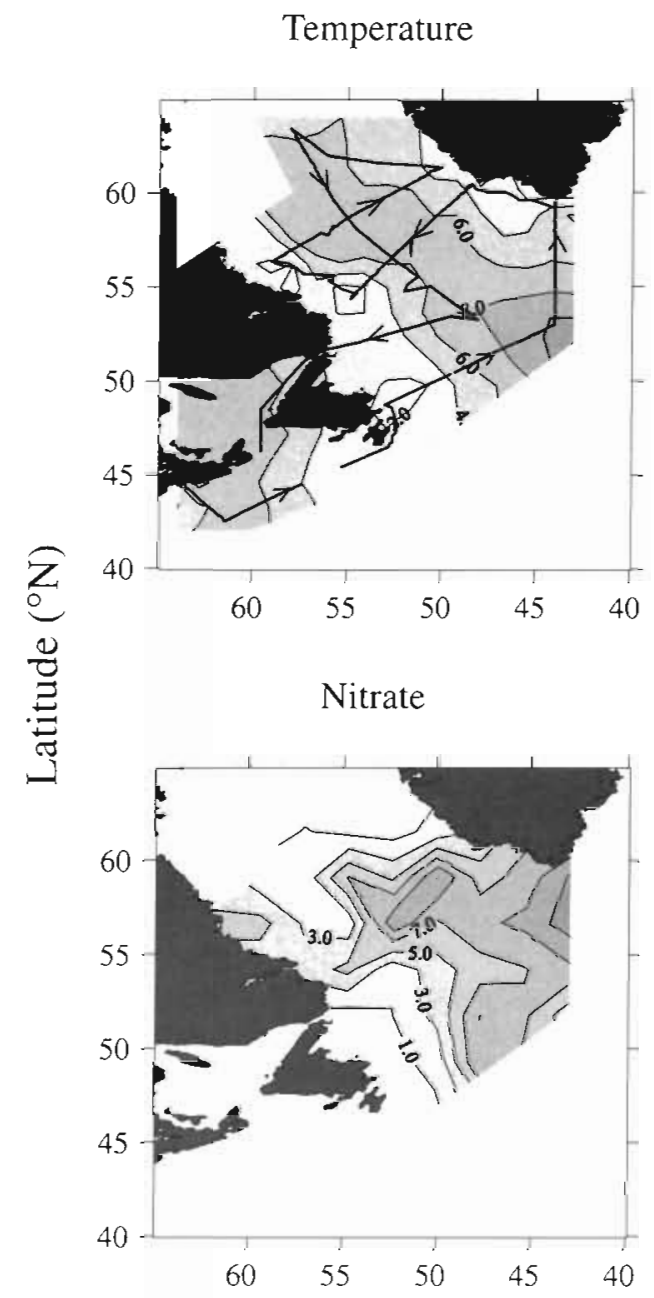

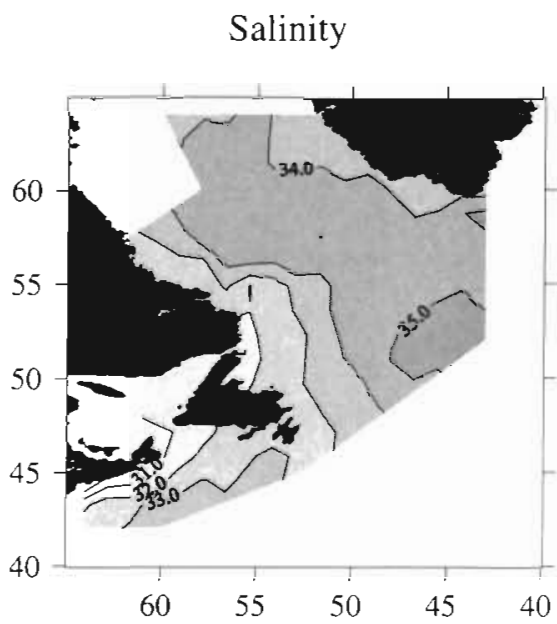

Fluorescence and surface chlorophyll concentration

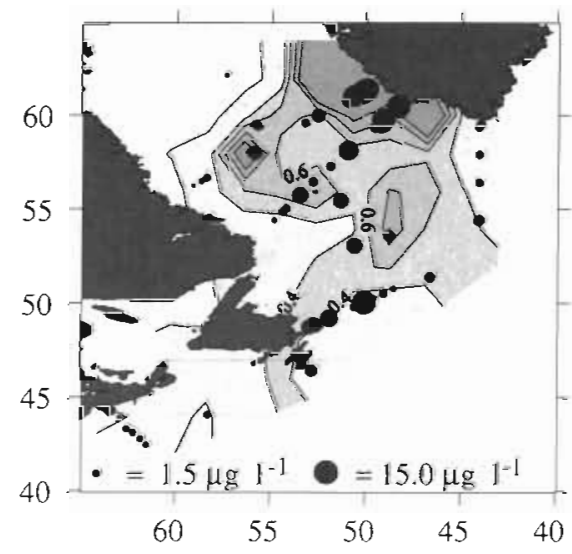

\section{Longitude $\left({ }^{\circ} \mathrm{W}\right)$}

Fig. 2. Contour plots of temperature $\left({ }^{\circ} \mathrm{C}\right)$, salinity, nitrate concentration $(\mu \mathrm{M})$ and fluorescence $(\mathrm{m} V)$ and chlorophyll concentration ( $\mathrm{\mu g} \mathrm{\textrm {I } ^ { - 1 }}$ ) in the near-surface $(5 \mathrm{~m}$ ) of the sampling region, compiled from data collected by the continuous flow-through system (see 'Materials and methods'). Upper left-hand panel shows the ship's track 
standing of the circulation patterns (Fig. 3): near-surface temperatures and salinities were highest $\left(>8^{\circ} \mathrm{C}\right.$ and $>34$, respectively) in the south and east, in areas most influenced by the North Atlantic Current, and relatively warm, salty water extended northwest throughout the central Labrador Sea. The near-surface waters over the shelves were cooler and fresher $\left(<0^{\circ} \mathrm{C}\right.$ and $<33$, respectively), and this cool, fresh water extended south over the eastern Newfoundland Shelf and on to the Grand Bank in the west, while being confined to a narrow band around the southern tip of Greenland in the east. High near-surface nitrate concentrations $(>7 \mu \mathrm{M})$ were generally associated with the warm salty waters in the south central Labrador Sea and farther to the southeast. The lowest nitrate concentrations were found in the north central Labrador Sea, over the north Greenland Shelf and over the Newfoundland Shelf, Grand Bank and farther to the southwest. On this cruise, although estimates of extracted chlorophyll concentrations co-varied with measurements of fluorescence for water collected by the continuous monitoring system (Fig. 2, lower right-hand panel), the 2 were not well correlated. This was also true for profiles of extracted chlorophyll compared with the fluorometers on the CTD rosette and biological pump, perhaps because of variations in fluorescence yield between different phytoplankton populations. For this reason, fluorescence measurements in Fig. 2 and elsewhere are shown as voltages, rather than as calculated chlorophyll concentrations. Nearsurface fluorescence levels and were highest on the Greenland Shelf, where extracted near-surface chlorophyll concentrations were $>10 \mu \mathrm{gl}^{-1}$, and much lower in the north central region, where extracted near-surface concentrations were $<1 \mu \mathrm{g} \mathrm{l}^{-1}$. Elsewhere, there were patches where fluorescence was high, relative to an intermediate background level.

\section{Profiles of temperature, salinity, nitrate concentra- tions and fluorescence at fixed stations}

Contour plots of profiles ( 0 to $100 \mathrm{~m}$ ) of temperature and salinity along the sampling lines (Figs. 4 \& 5) show values in the near-surface layer that follow the same spatial trends as those compiled from the continuous monitoring system: highest temperatures and salinities occurred in the offshore regions of lines $\mathrm{L} 4\left(6.9^{\circ} \mathrm{C}, 34.8\right)$ and $\mathrm{BON}\left(8.3^{\circ} \mathrm{C}, 34.9\right)$ (Fig. 4) and at the southern ends of lines L5 $\left(7.7^{\circ} \mathrm{C}, 34.9\right)$ and L6 $\left(6.9^{\circ} \mathrm{C}, 34.8\right)$ (Fig. 5). There were hydrographic fronts along both the Labrador (and Newfoundland) and Greenland shelves (L2, L3, L4, BON, L5), with warm salty water offshore and cool fresh water over the shelves. Along the Labrador Shelf, the frontal zone apparently broadened

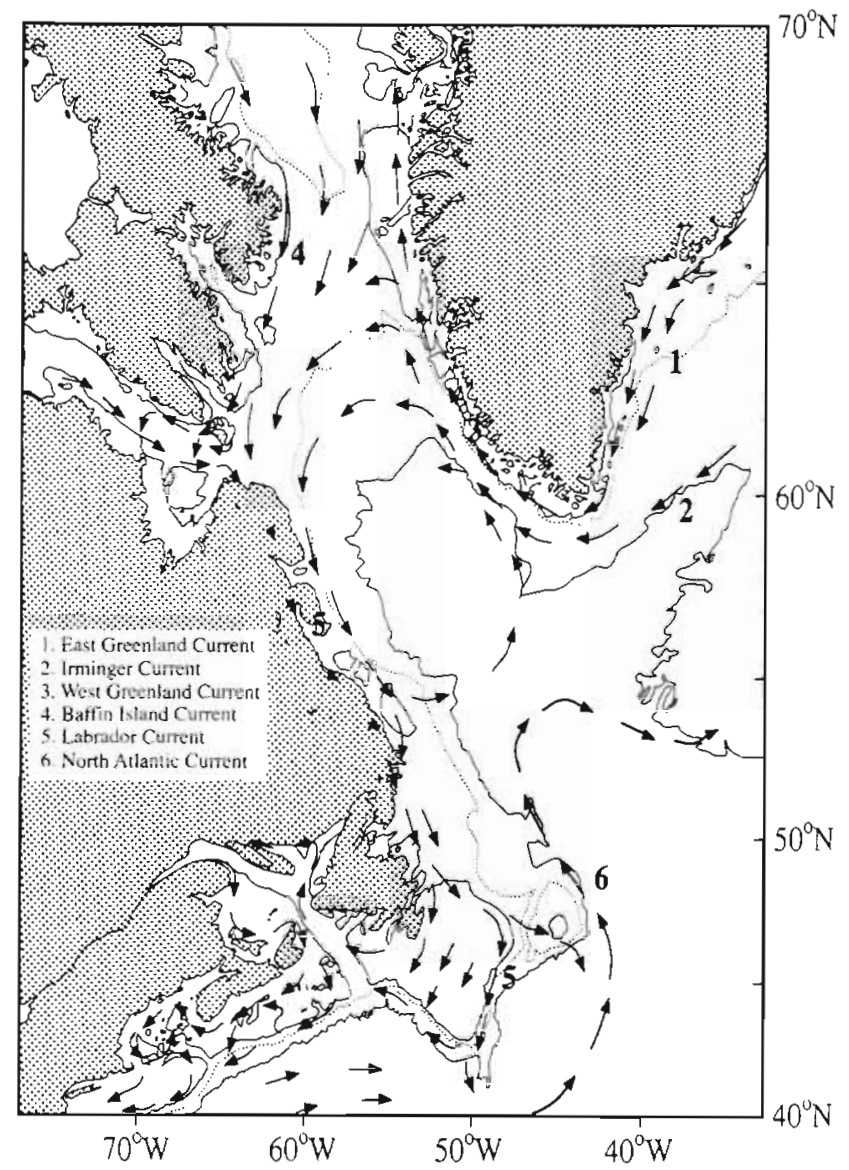

Fig. 3. Near-surface circulation of the main currents in the Labrador Sea sampling region. Contours are at 200,1000 and $3000 \mathrm{~m}$

from north (ca $20 \mathrm{~km}$ wide on the L2 line) to south (ca $80 \mathrm{~km}$ wide on the BON line) and there was indication of the advection of near-surface $(0$ to $30 \mathrm{~m}$ ) shelf water to the offshore extending offshore ca $50 \mathrm{~km}$ beyond the shelf-break at the eastern end of the L2 line and about the same distance beyond the shelf-break at the western end of the L3 line, leading to higher density stratification in those areas. The near-surface waters were slightly warmer (by ca $1^{\circ} \mathrm{C}$ ) than those underlying in some areas of the deep central Labrador Sea (L2, L3, L6), perhaps due to intrusions of Atlantic water, in the areas where the salinity was also higher (e.g. L3 line), or because of local warming. Over the Labrador Shelf on the L4 line, near-surface layers were also warmer than the underlying layers. Solar warming was probably responsible: the line was sampled at the end of the cruise in June and the weather had been generally fine.

The vertical and horizontal resolution of the nutrient data was less than for the other variables. Nevertheless, profiles of nitrate concentration (Figs. 6 \& 7) showed near-surface levels which were consistent with the spatial patterns produced by the continuous monitoring sys- 
Temperature

$\mathrm{L} 2$

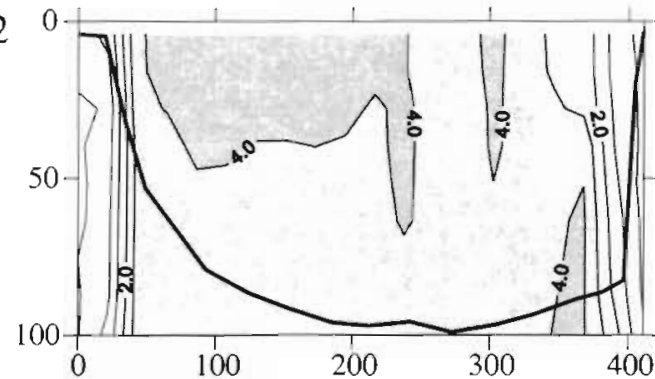

L4
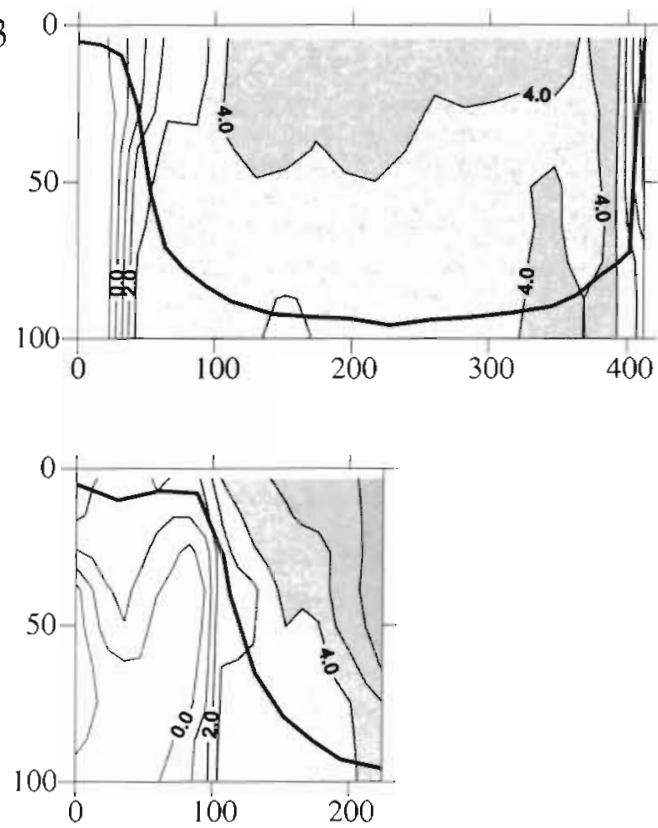

$\mathrm{BON}$

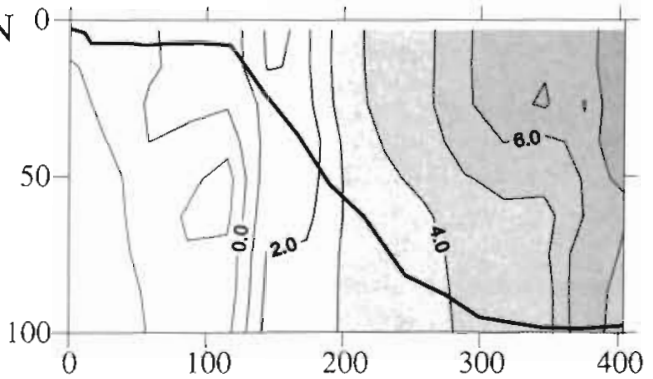

Salinity
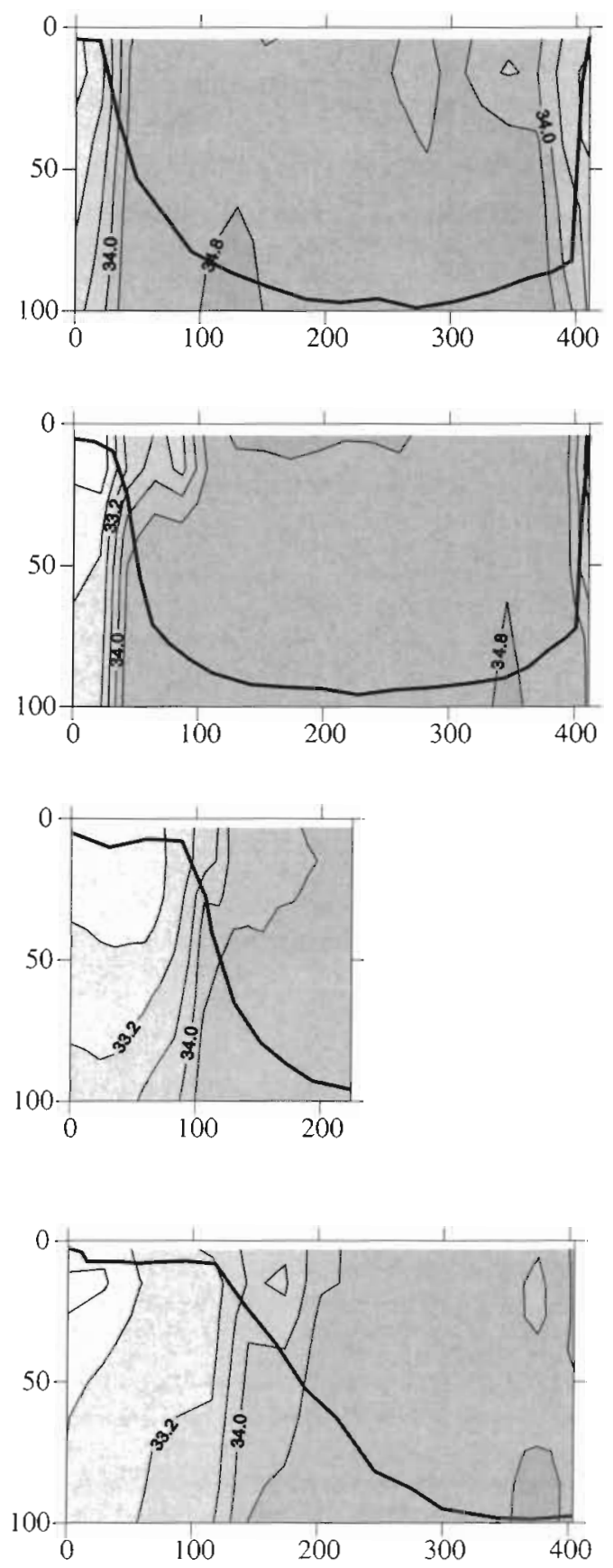

Distance from western end of transect $(\mathrm{km})$

Fig. 4. Contoured profiles of temperature $\left({ }^{\circ} \mathrm{C}\right)$ and salinity collected at $1 \mathrm{~m}$ depth intervals using the CTD rosette sampler for lines orientated west (left) to east (right). The $y$-axis is the depth in meters and the heavy line overlays show the bathymetry along each line: the deepest point in each case is $>3000 \mathrm{~m}$ (not drawn to scale)

tem (Fig. 2). Near-surface concentrations were relatively low $(<3 \mu \mathrm{M})$ in the north central Labrador Sea $(\mathrm{L} 2, \mathrm{~L} 6)$, over the northern Greenland Shelf (L2), in the frontal shelf-break region of the central Labrador Shelf (L4), and over the Newfoundland Shelf ( $\mathrm{L} 4, \mathrm{BON})$. They were high $(>7 \mu \mathrm{M})$, however, in some areas of the central Labrador Sea (L3) and at offshore stations in the south (BON) and southeast (L5, L6). At stations where surface 

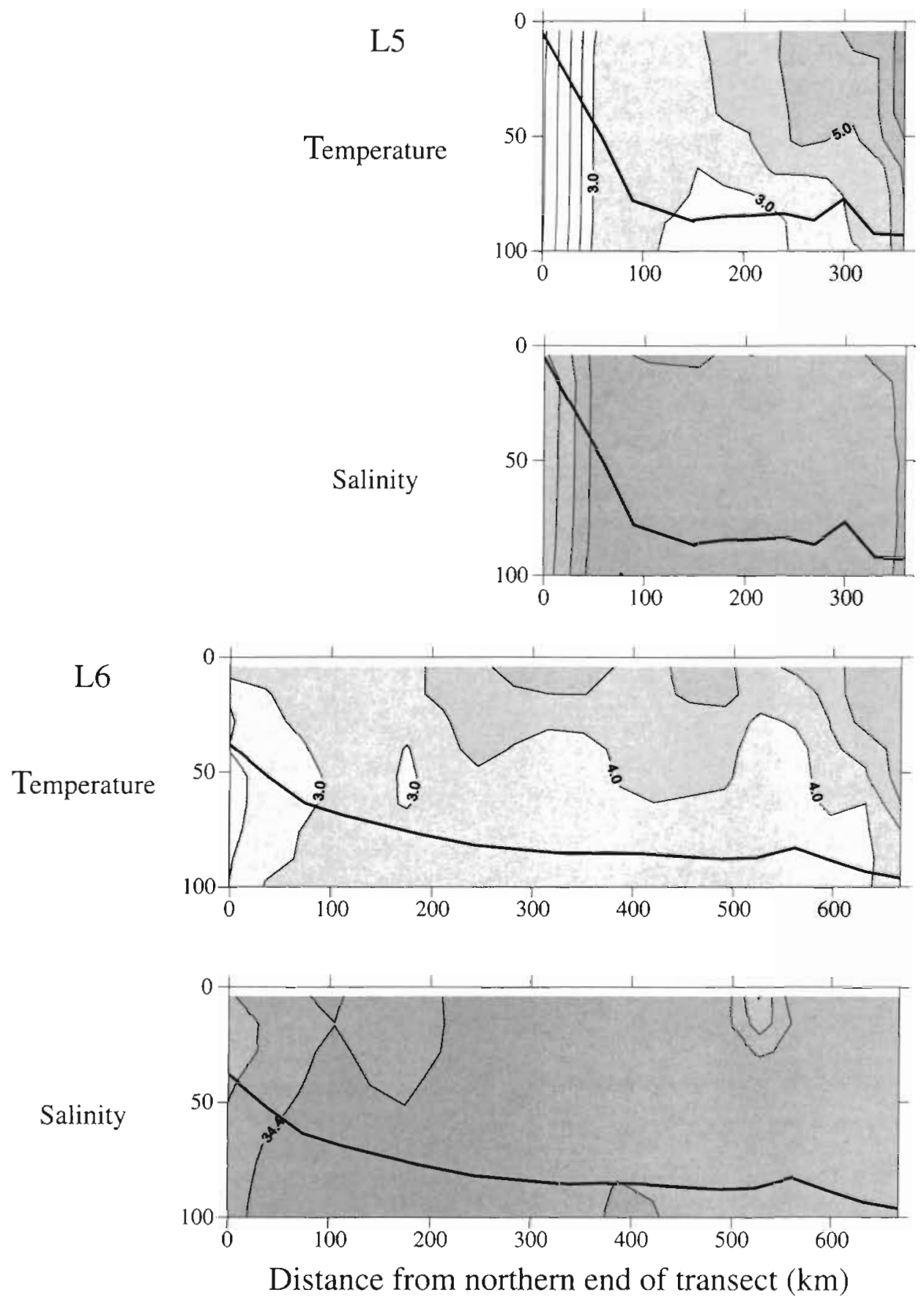

Fig. 5. Contoured profiles of temperature $\left({ }^{\circ} \mathrm{C}\right)$ and salinity collected at $1 \mathrm{~m}$ depth intervals using the CTD rosette sampler for lines orientated north (left) to south (right). The $y$-axis is the depth in meters and the heavy line overlays show the bathymetry along each line: the deepest point in each case is $>3000 \mathrm{~m}$ (not drawn to scale)

nitrate levels were low, concentrations at $50 \mathrm{~m}$ were $>5 \mu \mathrm{M}$, except along the shelf-break on the northern Greenland Shelf (L2), where the nitrate concentration at $50 \mathrm{~m}$ was $2.5 \mu \mathrm{M}$ and at $100 \mathrm{~m}$ was still only $3 \mu \mathrm{M}$.
The continuous monitoring system showed patches of enhanced fluorescence that were 20 to $50 \mathrm{~km}$ wide. The profiles showed that fluoresence was often maximal at the surface or within the 0 to $20 \mathrm{~m}$ depth range. 
Nitrate

L2

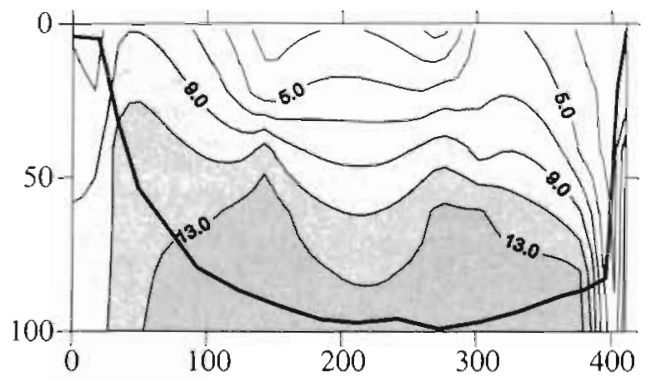

L3

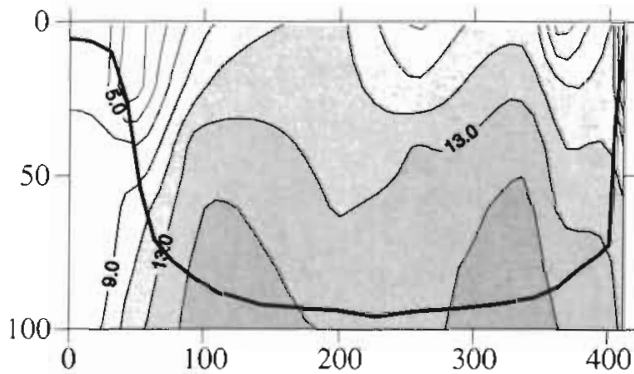

L4

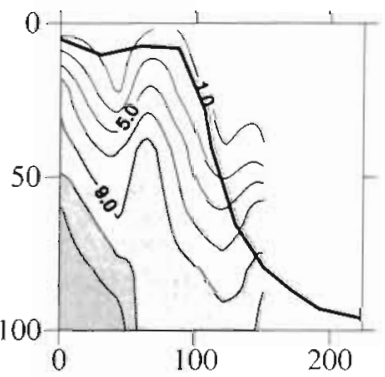

BON

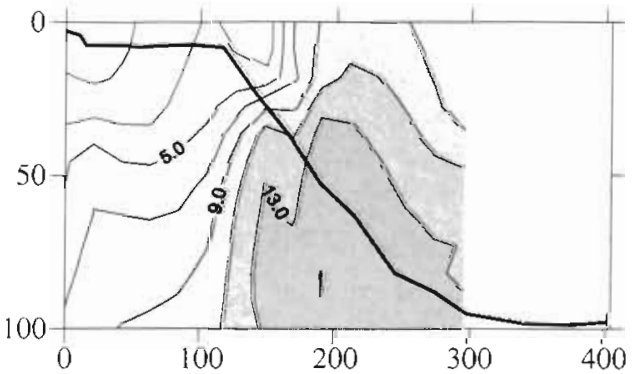

Fluorescence
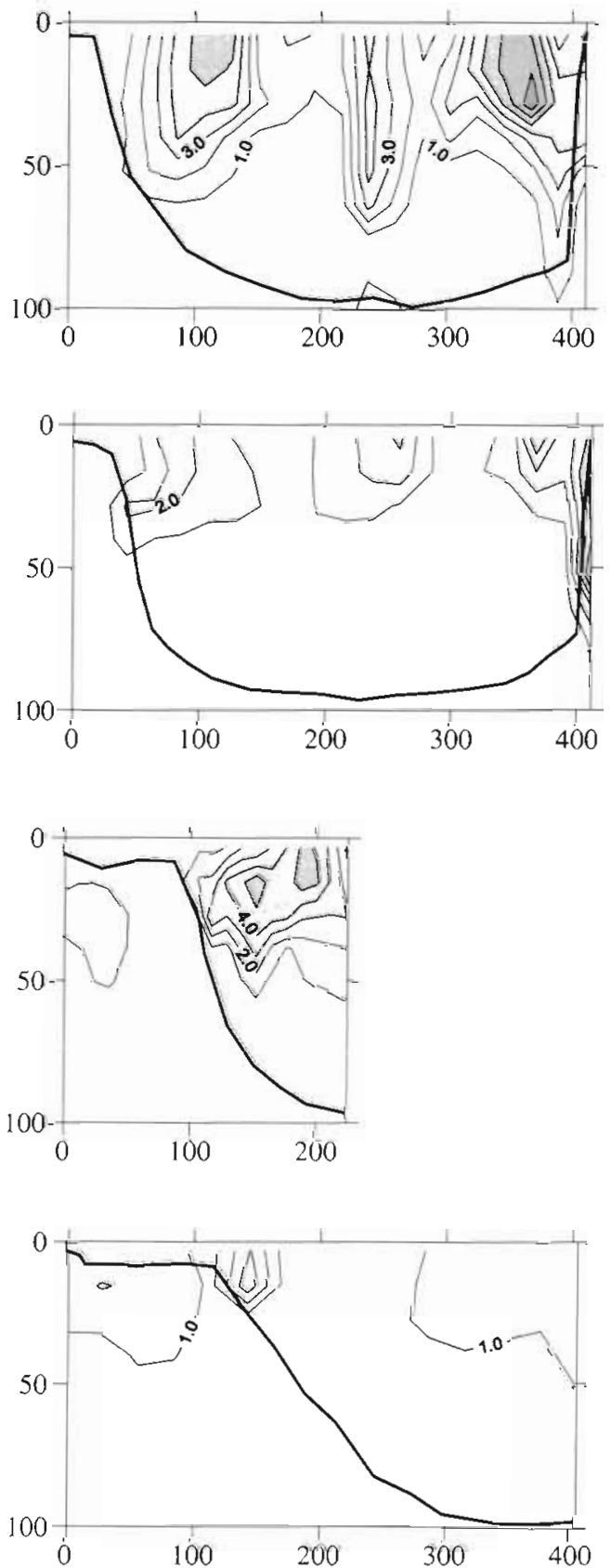

Distance from western end of transect $(\mathrm{km})$

Fig. 6. Contoured profiles of nitrate concentration $(\mu \mathrm{M})$ collected at $10 \mathrm{~m}$ depth intervals using the biological pump and of fluorescence collected at $1 \mathrm{~m}$ depth intervals using the CTD rosette samplex. Line orientation and bathymetry as in Fig. 4

Areas of most intense fluoresence were midway along the sections accross the northern central and central Labrador Sea (L2, L3), near the western and eastern margins of the central basin (L2, L3, L4) and on the central Greenland Shelf (L2, L3). Profiles of nitrate concentration and phytoplankton fluorescence were not obviously related, i.e. areas where fluorescence was high did not necessarily correspond to areas where near-surface nitrate levels were low and vice versa. 
L5

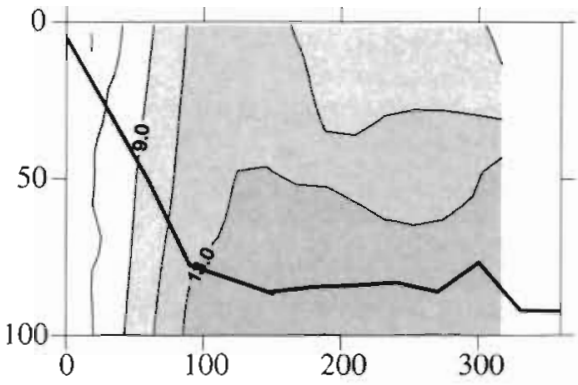

Fluorescence

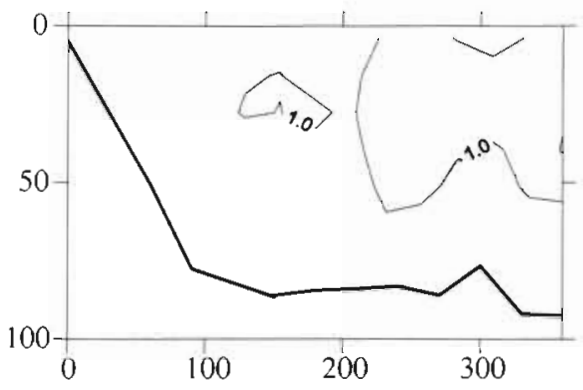

L6

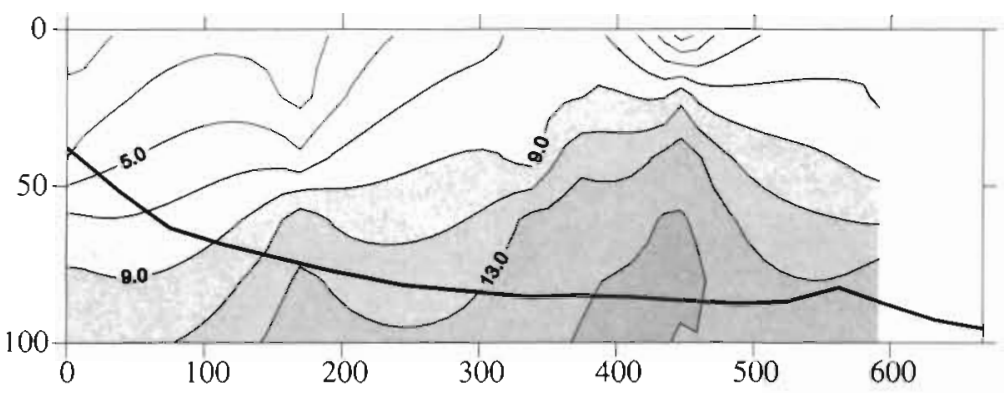

Fluorescence

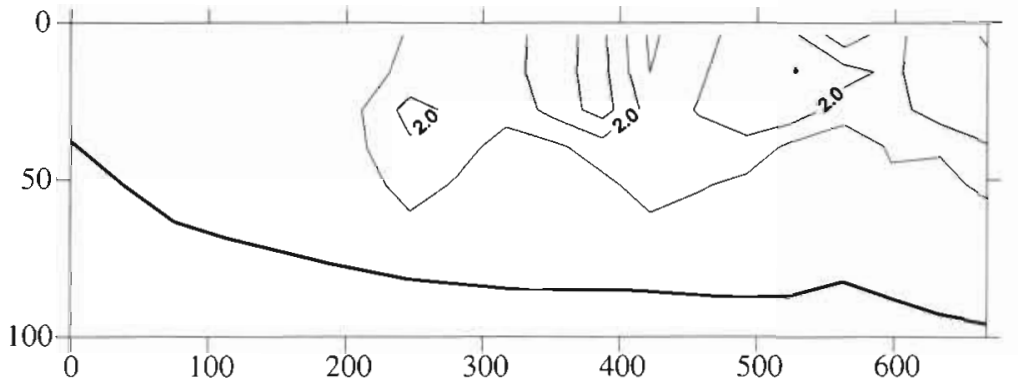

Distance from northern end of transect $(\mathrm{km})$

Fig. 7. Contoured profiles of nitrate concentration $(\mu \mathrm{M})$ collected at $10 \mathrm{~m}$ depth intervals using the biological pump and of fluorescence collected at $1 \mathrm{~m}$ depth intervals using the CTD rosette sampler. Line orientation and bathymetry as in Fig. 5

\section{Distribution of abundance and biomass of Calanus finmarchicus in the Labrador Sea}

The early stages (CI-IIIs) dominated the pattern of abundance of Calanus finmarchicus copepodites overall, with highest values in the northern Labrador Sea
(L6) and near the margins of the central basin on the L2 line (Fig. 8, Table 1). The CIs were generally the most abundant, showing a maximum value of ca $80000 \mathrm{~m}^{-2}$ (L2 Stn 14; Table 1). At some stations, however, CIs were outnumbered by CIIs and CIIIs (L2 Stns 2, 3 and $6 ;$ L6 Stns 13 and 15; Tables $1 \& 2$ ) and the highest 

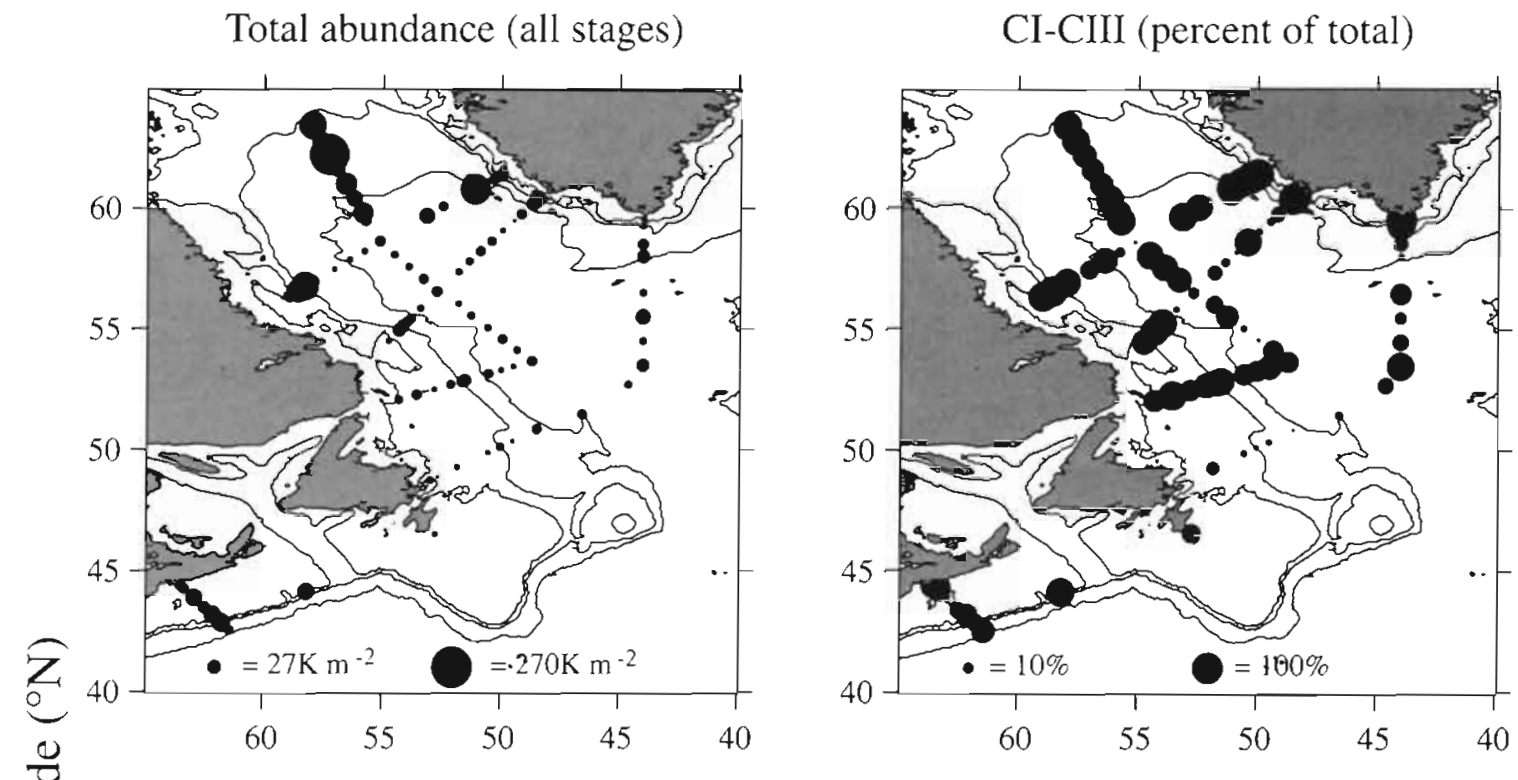

CIV-CV (percent of total)
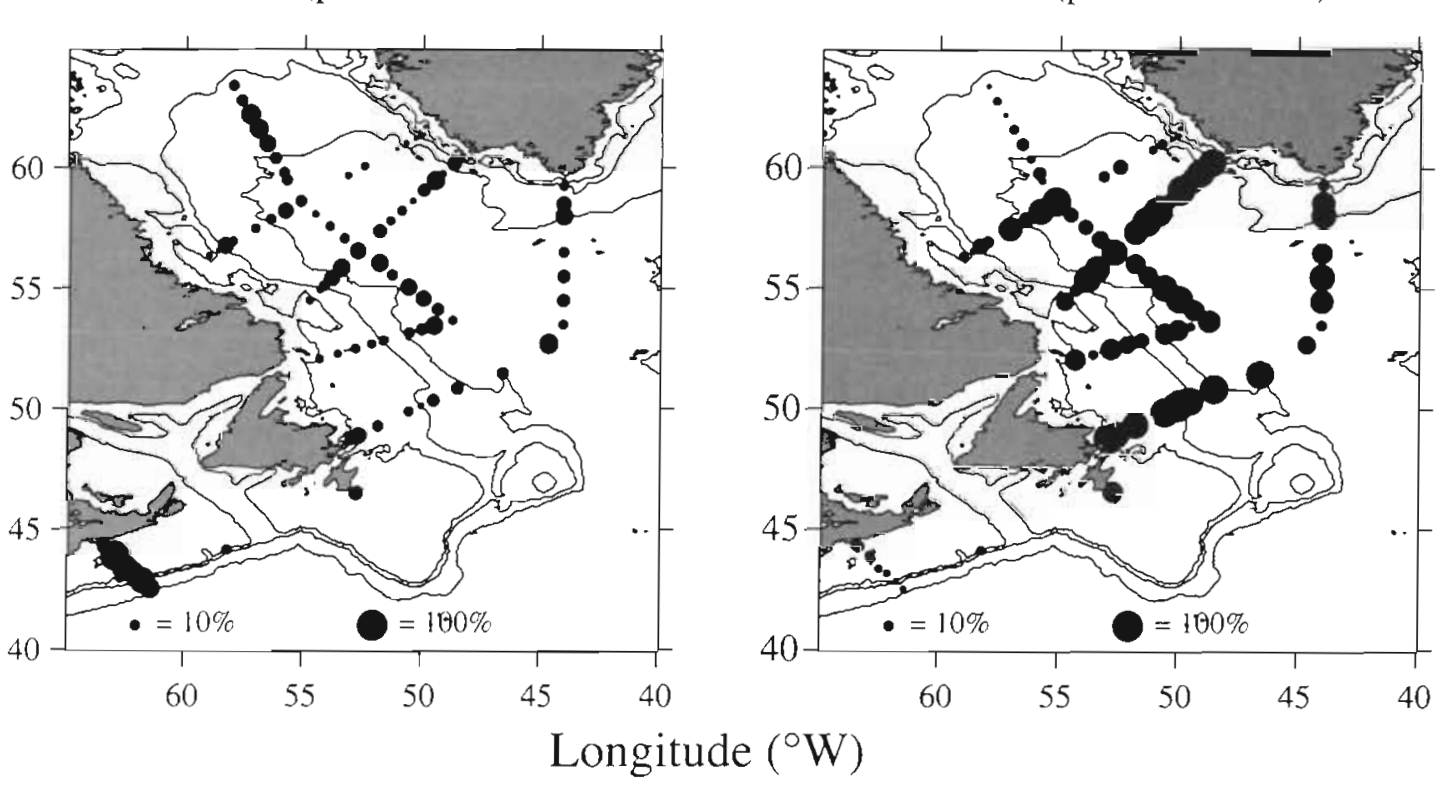

Fig. 8. Calanus finmarchicus. Abundance in the Labrador Sea in May-June 1997 The areas of the solid circles are proportional to the number of copepods $\mathrm{m}^{-2}$

abundance for any individual stage was CIII at ca $131000 \mathrm{~m}^{-2}$ (L6 Stn 16). In the Labrador Sea, stages CIV and CV were only numerous in the north (L6) and at 1 station at the Labrador shelf-break on the L.2 line (L2 Stn 2). Females generally outnumbered males by a factor of 5 or more and were themselves most abundant at the shelf-break station on the L2 line (ca $30000 \mathrm{mI}^{-2}$; L2 Stn 2), with next highest abundances in the southeast (L5), on the eastern side of the central Labrador Sea (L3) and in the south (BON Stns 13 and
16). Males had their highest abundances at stations on the L5 line and at stations of depth $>3000 \mathrm{~m}$ in the central Labrador Sea (Stns L2, L3 and L6) (Tables 1 \& 2). Along the HL on the Scotian Shelf, where the spring bloom occurred in April in 1997 (Head unpubI. data), CIVs and CVs were the most abundant stages, followed by CI-CIlls, and adults were relatively rare (Fig. 8).

In the Labrador Sea total Calanus finmarchicus biomass (Fig. 9) varied between a maximum of ca $20 \mathrm{~g}$ dry 
Table 1. Calanus finmarchicus. Abundances of individual stages along the latitudinal sections from west to east (no. $\mathrm{m}^{-2}$ )

\begin{tabular}{|c|c|c|c|c|c|c|c|c|c|}
\hline \multirow[t]{2}{*}{ Line } & \multirow[t]{2}{*}{ Stn } & \multicolumn{7}{|c|}{ Stage } & \multirow[t]{2}{*}{ Total } \\
\hline & & I & II & III & IV & V & VI F & VI M & \\
\hline $\mathrm{L} 2-\mathrm{BO}$ & 7 & 7955 & 3480 & 933 & 461 & 70 & 1182 & 0 & 14082 \\
\hline $\mathrm{L} 2$ & 1 & 49946 & 19585 & 7442 & 2054 & 411 & 3526 & 0 & 82965 \\
\hline $\mathrm{L} 2$ & 2 & 8136 & 21696 & 30510 & 17628 & 16950 & 31866 & 0 & 126786 \\
\hline $\mathrm{L} 2$ & 3 & 2825 & 12656 & 7910 & 1806 & 588 & 3770 & 226 & 29780 \\
\hline L2 & 5 & 610 & 407 & 136 & 90 & 203 & 1806 & 158 & 3410 \\
\hline L2 & 6 & 678 & 1806 & 1175 & 316 & 271 & 1220 & 90 & 5557 \\
\hline L2 & 7 & 298 & 199 & 0 & 75 & 1342 & 3232 & 547 & 5693 \\
\hline $\mathrm{L} 2$ & 8 & 90 & 45 & 0 & 181 & 2068 & 14012 & 768 & 17165 \\
\hline L2 & 11 & 18080 & 10848 & 3015 & 1406 & 588 & 4371 & 136 & 38443 \\
\hline $\mathbf{L} 2$ & 12 & 4371 & 3919 & 1085 & 158 & 678 & 2712 & 90 & 13013 \\
\hline $\mathrm{L} 2$ & 14 & 82363 & 45541 & 7051 & 1116 & 411 & 8520 & 59 & 145063 \\
\hline $\mathrm{L} 2$ & 15 & 8136 & 3616 & 1299 & 294 & 136 & 1356 & 0 & 14837 \\
\hline L2 & 16 & 9492 & 4746 & 1525 & 136 & 45 & 203 & 0 & 16148 \\
\hline L2 & 17 & 8136 & 4974 & 1299 & 90 & 0 & 68 & 0 & 14568 \\
\hline $\mathrm{L} 2$ & 18 & 8136 & 4522 & 1681 & 339 & 45 & 158 & 0 & 14882 \\
\hline L2 & 19 & 10297 & 9232 & 2106 & 323 & 25 & 348 & 0 & 22331 \\
\hline L3 & 5 & 2260 & 452 & 136 & 45 & 226 & 1487 & 0 & 4606 \\
\hline L3 & 6 & 6780 & 2486 & 452 & 316 & 181 & 2531 & 45 & 12792 \\
\hline L3 & 8 & 15368 & 4068 & 1921 & 859 & 362 & 3618 & 45 & 26241 \\
\hline L3 & 9 & 9718 & 5650 & 2170 & 1731 & 678 & 4070 & 158 & 24175 \\
\hline L3 & 10 & 9492 & 3315 & 960 & 490 & 264 & 1469 & 68 & 16060 \\
\hline L3 & 12 & 136 & 45 & 113 & 775 & 2441 & 9038 & 294 & 12841 \\
\hline L3 & 14 & 113 & 45 & 45 & 723 & 1469 & 4068 & 610 & 7074 \\
\hline L3 & 16 & 158 & 452 & 45 & 407 & 678 & 3164 & 54.2 & 5447 \\
\hline L3 & 17 & 655 & 542 & 249 & 945 & 384 & 3955 & 249 & 6979 \\
\hline L3 & 18 & 407 & 181 & 0 & 339 & 249 & 6780 & 497 & 8452 \\
\hline L3 & 19 & 0 & 68 & 113 & 226 & 1087 & 11752 & 497 & 13743 \\
\hline L3 & 20 & 90 & 0 & 90 & 475 & 226 & 3390 & 203 & 4475 \\
\hline L3 & 21 & 14 & 9 & 27 & 99 & 226 & 438 & 95 & 909 \\
\hline L3 & 22 & 1806 & 768 & 90 & 136 & 497 & 10846 & 407 & 14550 \\
\hline L3 & 24 & 362 & 316 & 226 & 452 & 5424 & 19888 & 1304 & 27972 \\
\hline L3 & 25 & 4746 & 1977 & 438 & 102 & 124 & 933 & 68 & 8389 \\
\hline L3 & 26 & 22148 & 12656 & 2441 & 271 & 203 & 1175 & 11 & 38906 \\
\hline L3 & 27 & 8362 & 3955 & 994 & 384 & 136 & 1469 & 68 & 15368 \\
\hline L4 & 1 & 2599 & 1921 & 712 & 136 & 542 & 4520 & 181 & 10611 \\
\hline L4 & 2 & 7533 & 3435 & 1989 & 484 & 423 & 1268 & 61 & 15192 \\
\hline L4 & 3 & 1431 & 301 & 129 & 271 & 90 & 1731 & 181 & 4134 \\
\hline L4 & 4 & 4068 & 1446 & 960 & 316 & 497 & 2938 & 136 & 10362 \\
\hline L4 & 5 & 7684 & 4070 & 3015 & 814 & 814 & 3315 & 45 & 19757 \\
\hline L4 & 6 & 8362 & 6554 & 2825 & 407 & 407 & 4972 & 90 & 23617 \\
\hline L4 & 8 & 3164 & 1957 & 904 & 136 & 1469 & 5650 & 271 & 13551 \\
\hline L4 & 9 & 1058 & 764 & 181 & 113 & 520 & 1883 & 90 & 4608 \\
\hline L4 & 10 & 1806 & 407 & 23 & 68 & 1187 & 203 & 45 & 3738 \\
\hline L4 & 11 & 2057 & 768 & 226 & 316 & 814 & 2608 & 339 & 7128 \\
\hline$B O N$ & 1 & 0 & 0 & 0 & 226 & 678 & 5876 & 0 & 6780 \\
\hline BON & 3 & 0 & 0 & 0 & 75 & 149 & 547 & 99 & 870 \\
\hline $\mathrm{BON}$ & 6 & 755 & 0 & 0 & 226 & 339 & 3166 & 90 & 4577 \\
\hline BON & 9 & 118 & 0 & 0 & 176 & 118 & 2642 & 59 & 3112 \\
\hline BON & 10 & 181 & 0 & 0 & 181 & 226 & 9492 & 181 & 10260 \\
\hline BON & 11 & 68 & 0 & 0 & 271 & 113 & 1806 & 68 & 2326 \\
\hline $\mathrm{BON}$ & 13 & 45 & 0 & 0 & 1175 & 1085 & 11300 & 452 & 14057 \\
\hline $\mathrm{BON}$ & 16 & 158 & 316 & 362 & 113 & 1883 & 10396 & 68 & 13296 \\
\hline $\mathrm{BON}$ & 19 & 181 & 362 & 1550 & 904 & 2558 & 2441 & 362 & 8357 \\
\hline
\end{tabular}


Table 2. Calanus finmarchicus. Abundances of individual stages along the longitudinal sections from north to south (no. $\mathrm{m}^{-2}$ )

\begin{tabular}{|c|c|c|c|c|c|c|c|c|c|}
\hline Line & Stn & I & II & III & $\begin{array}{c}\text { Stage } \\
\text { IV }\end{array}$ & V & VIF & VI M & Total \\
\hline L5 & 27 & 3618 & 551 & 203 & 45 & 0 & 36 & 7 & 4461 \\
\hline L5 & 26 & 2825 & 1356 & 382 & 169 & 254 & 610 & 23 & 5619 \\
\hline L5 & 24 & 2097 & 933 & 617 & 1333 & 3173 & 9695 & 979 & 18828 \\
\hline L5 & 23 & 181 & 181 & 316 & 2825 & 5424 & 13560 & 2893 & 25380 \\
\hline L5 & 20 & 2260 & 1058 & 316 & 158 & 707 & 2133 & 1130 & 7763 \\
\hline L5 & 18 & 2642 & 1695 & 588 & 823 & 5141 & 22916 & 1351 & 35157 \\
\hline L5 & 16 & 1193 & 522 & 398 & 199 & 1193 & 4473 & 124 & 8102 \\
\hline L5 & 14 & 11752 & 6328 & 2983 & 1742 & 588 & 2531 & 90 & 26015 \\
\hline L6 6 & 18 & 55402 & 34119 & 16814 & 11049 & 3098 & 2170 & 0 & 122652 \\
\hline L6 & 17 & 25764 & 10712 & 4068 & 3526 & 3254 & 3119 & 0 & 50443 \\
\hline L6 & 16 & 3164 & 16950 & 131080 & 83620 & 21093 & 4972 & 0 & 260879 \\
\hline L6 & 15 & 2441 & 5650 & 10848 & 9944 & 2967 & 2967 & 0 & 34818 \\
\hline L6 & 14 & 12430 & 17402 & 11933 & 18396 & 2287 & 10608 & 0 & 73057 \\
\hline L6 & 13 & 9492 & 11300 & 10848 & 4515 & 904 & 2441 & 181 & 39681 \\
\hline L6 & 12 & 22781 & 14645 & 10848 & 5641 & 1519 & 10125 & 289 & 65847 \\
\hline L6 & 11 & 9284 & 3810 & 2859 & 1243 & 1094 & 796 & 199 & 19285 \\
\hline L6 & 9 & 4371 & 1731 & 384 & 203 & 203 & 1681 & 68 & 8642 \\
\hline L6 & 8 & 3763 & 994 & 316 & 316 & 271 & 1356 & 181 & 7198 \\
\hline L6 & 7 & 3616 & 2599 & 2712 & 588 & 814 & 4215 & 45 & 14588 \\
\hline L6 & 5 & 911 & 373 & 174 & 75 & 1492 & 1740 & 224 & 4988 \\
\hline L6 & 4 & 3763 & 1085 & 475 & 113 & 1019 & 3611 & 158 & 10224 \\
\hline L6 & 3 & 50 & 50 & 199 & 0 & 2188 & 4805 & 348 & 7639 \\
\hline L6 & 2 & 0 & 45 & 45 & 45 & 3164 & 9040 & 497 & 12837 \\
\hline L6 & 1 & 4339 & 1898 & 316 & 127 & 1012 & 7087 & 316 & 15097 \\
\hline
\end{tabular}

wt $\mathrm{m}^{-2}$ at the Labrador shelf-break of the L2 line (L2 Stn 2; Table 3) and a minimum of ca $42 \mathrm{mg}$ dry $w \mathrm{t} \mathrm{m}^{-2}$ on the shelf at the southern tip of Greenland (L5-27; Table 4). Adults generally dominated the total biomass, except at stations in the northern Labrador Sea (L6 Stns 14, 15, 16, 17 and 18) and at L2 Stn 2, where CVIs and CVs made important contributions. CIVs and CVs also dominated the biomass at stations of the HL on the Scotian Shelf.

\section{Egg production rates and naupliar abundance versus the state of the spring bloom}

In Fig. 10, we have divided the sampling area into 4 different zones based on the concentration of nitrate obtained from the continuous monitoring system (at ca $5 \mathrm{~m}$ depth). In the dark grey zone, covering the southeast region and central Labrador Sea, near-surface nitrate levels were $>6 \mu \mathrm{M}$. In this area, chlorophyll concentrations were generally relatively low and we have designated this an 'early bloom' zone. The actual value $(6 \mu M)$ was chosen somewhat arbitrarily, and corresponds to a nitrate concentration of roughly one-half the highest values generally seen in the profiles to $100 \mathrm{~m}$. In the intermediately coloured zone, covering the north central Labrador Sea and the Labrador Shelf, near-surface nitrate concentrations were between 1 and $6 \mu \mathrm{M}$. Integrated chlorophyll concentrations were variable, but often high, and we have therefore designated this a 'bloom' zone. In the 2 light grey zones, one in the northern Labrador Sea and the other over the Newfoundland Shelf and to the southwest, near-surface nitrate concentrations were $<1 \mu \mathrm{M}$. Integrated chlorophyll concentrations were variable and we have designated these 'late' or 'post-bloom' zones. For near-surface water samples from profiles collected in the 3 zones (Table 5), average nitrate concentrations were highest in the early bloom zone, intermediate in the bloom zone and lowest in the late/post-bloom zone $(\mathrm{p}<0.001)$. The average integrated chlorophyll concentration was lower in the early bloom zone than those in either the bloom or late/post-bloom zones.

Egg production rates were measured experimentally as average rates determined for groups of 20 to 30 females from 50 stations which were incubated individually (Campbell 1998, Campbeli \& Head 2000). 

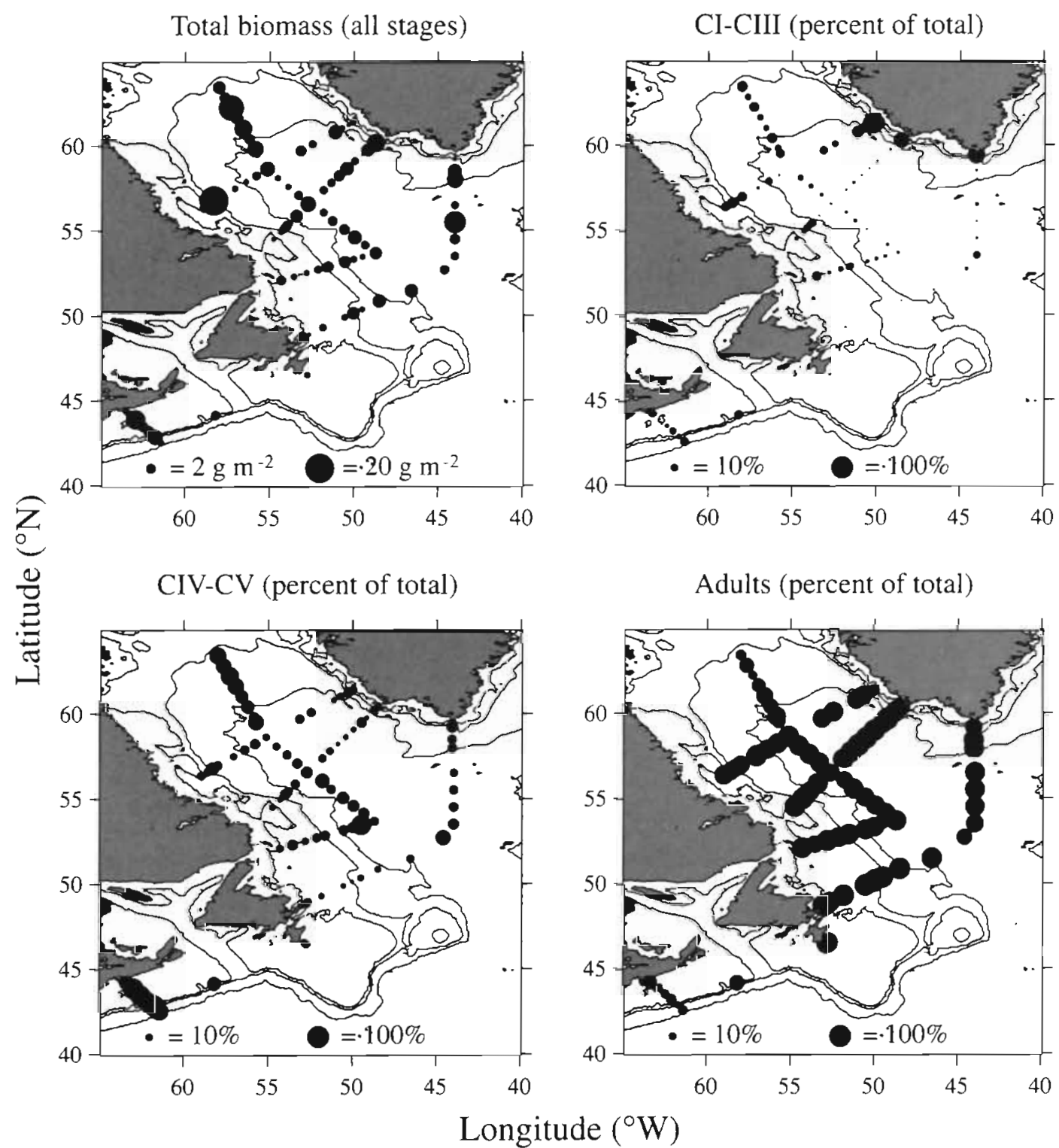

Fig. 9. Calanus finmarchicus. Biomass in the Labrador Sea in May-June 1997. The areas of the solid circles are proportional to the dry weight of copepods $\mathrm{m}^{-2}$

When results were grouped by zones (Table 5), the average rate was higher in the early bloom zone than in either the bloom or late/post-bloom zones. Few, if any, eggs were produced at late/post-bloom stations in the northern Labrador Sea (L6 Stns 16 and 18) and at bloom L2 Stn 1 and L2 Stn 2. Average female abundance did not vary significantly between the zones $(p>0.1)$, although it was highest in the early bloom zone, intermediate in the bloom zone and lowest in the late/post-bloom zones (Table 5). Areal estimates of egg production rate followed the same pattern as that of individual egg production rates: values were significantly higher in the early bloom zone than in either the bloom or late/postbloom zones. Areal estimates of egg production rate and female abundances were closely correlated $(\mathrm{p}<$ 0.001; also, cf. Figs. $8 \& 10$ ) primarily because while average female egg production rates varied by only a factor of 50 between stations (excluding the zero values), female abundances varied by a factor of ca $10^{3}$.

Estimates of relative abundance of Calanus spp. nauplii were made for the zooplankton samples collected using a $200 \mu \mathrm{m}$ mesh net (Fig. 10). Since C. 
Table 3. Calanus finmarchicus. Biomasses of individual stages along the latitudinal sections from west to east (mg dry wt $\mathrm{m}^{-2}$ )

\begin{tabular}{|c|c|c|c|c|c|c|c|c|c|}
\hline \multirow[t]{2}{*}{ Line } & \multirow[t]{2}{*}{ Stn } & \multicolumn{7}{|c|}{ Stage } & \multirow[t]{2}{*}{ Total } \\
\hline & & I & II & III & IV & V & VIF & VI M & \\
\hline $\mathrm{L} 2-\mathrm{BO}$ & 7 & 20.8 & 22.4 & 24.4 & 47.5 & 8.6 & 374.7 & 0.0 & 498.3 \\
\hline L2 & 1 & 1087 & 1401 & 178.3 & 173.6 & 109.6 & 1296.8 & 0.0 & 2007.1 \\
\hline $\mathrm{L} 2$ & 2 & 224 & 1944 & 688.2 & 1955.4 & 4470.1 & 12320.6 & 0.0 & 19650.9 \\
\hline $\mathrm{L} 2$ & 3 & 10.8 & 1532 & 2129 & 174.5 & 163.2 & 1389.4 & 64.6 & 2168.7 \\
\hline $\mathrm{L} 2$ & 5 & 23 & 47 & 36 & 8.1 & 63.5 & 715.3 & 37.7 & 835.3 \\
\hline L2 & 6 & 27 & 19.7 & 35.9 & 30.5 & 76.6 & 420.1 & 24.0 & 609.5 \\
\hline L2 & 7 & 1.1 & 2.7 & 0.0 & 8.1 & 300.8 & 1086.6 & 147.4 & 1546.7 \\
\hline $\mathrm{L} 2$ & 8 & 00 & 0.5 & 0.0 & 14.5 & 487.5 & 4261.0 & 210.4 & 4973.8 \\
\hline L2 & 11 & 759 & 116.2 & 133.3 & 189.8 & 217.6 & 1761.7 & 44.5 & 2539.1 \\
\hline L2 & 12 & 15.6 & 42.9 & 37.1 & 18.1 & 190.5 & 1013.8 & 22.6 & 1340.6 \\
\hline L2 & 14 & 298.3 & 590.5 & 233.2 & 122.3 & 134.0 & 3064.6 & 21.7 & 4464.6 \\
\hline L2 & 15 & 32.3 & 40.5 & 44.5 & 25.1 & 37.3 & 438.2 & 0.0 & 617.9 \\
\hline $\mathrm{L} 2$ & 16 & 40.5 & 53.6 & 47.7 & 12.4 & 12.9 & 65.1 & 0.0 & 232.1 \\
\hline $\mathrm{L} 2$ & 17 & 33.9 & 68.5 & 42.3 & 7.9 & 0.0 & 17.9 & 0.0 & 170.4 \\
\hline $\mathrm{L} 2$ & 18 & 48.8 & 77.3 & 61.0 & 29.2 & 12.0 & 48.6 & 0.0 & 276.9 \\
\hline L2 & 19 & 51.5 & 95.1 & 53.6 & 29.6 & 5.7 & 87.7 & 0.0 & 323.2 \\
\hline L3 & 5 & 6.6 & 2.9 & 2.5 & 3.4 & 34.1 & 418.3 & 0.0 & 467.8 \\
\hline L3 & 6 & 19.4 & 16.0 & 12.4 & 23.3 & 22.4 & 747.2 & 8.8 & 849.5 \\
\hline L3 & 8 & 41.1 & 37.5 & 59.9 & 71.6 & 87.2 & 1337.9 & 12.2 & 1647.5 \\
\hline L3 & 9 & 357 & 58.3 & 68.0 & 256.3 & 205.2 & 1455.4 & 0.0 & 2079.0 \\
\hline L3 & 10 & 416 & 28.5 & 35.5 & 58.5 & 68.9 & 571.3 & 17.6 & 822.0 \\
\hline L3 & 12 & 0.5 & 0.2 & 2.5 & 83.8 & 495.6 & 2882.6 & 84.1 & 3549.3 \\
\hline L3 & 14 & 0.5 & 0.5 & 1.1 & 78.0 & 323.4 & 1353.7 & 171.5 & 1928.7 \\
\hline L3 & 16 & 0.5 & 3.8 & 0.9 & 38.6 & 142.2 & 1087.7 & 131.3 & 1405.0 \\
\hline L3 & 17 & 2.5 & 6.3 & 8.4 & 90.4 & 61.9 & 1260.6 & 64.6 & 1494.8 \\
\hline L3 & 18 & 1.4 & 1.6 & 0.0 & 33.4 & 36.8 & 2374.6 & 139.2 & 2587.0 \\
\hline L3 & 19 & 0.0 & 0.7 & 2.9 & 21.0 & 185.3 & 3637.2 & 118.9 & 3966.1 \\
\hline L3 & 20 & 0.2 & 0.0 & 1.8 & 38.0 & 36.6 & 1106.7 & 49.0 & 1232.4 \\
\hline L3 & 21 & 0.0 & 0.0 & 0.0 & 8.4 & 31.4 & 129.3 & 21.5 & 190.5 \\
\hline L3 & 22 & 7.5 & 9.0 & 3.6 & 10.8 & 99.7 & 3595.9 & 115.9 & 3842.5 \\
\hline L3 & 24 & 1.1 & 2.3 & 6.6 & 42.7 & 1127.1 & 5978.6 & 342.8 & 7501.2 \\
\hline L 3 & 25 & 20.6 & 27.1 & 12.0 & 7.2 & 29.6 & 254.5 & 17.9 & 368.8 \\
\hline L3 & 26 & 84.1 & 164.5 & 88.1 & 20.6 & 41.8 & 296.3 & 2.9 & 698.3 \\
\hline L3 & 27 & 35.3 & 50.9 & 28.9 & 29.6 & 25.5 & 425.6 & 12.9 & 608.6 \\
\hline L4 & 1 & 14.0 & 28.2 & 26.0 & 18.8 & 193.9 & 1636.9 & 47.7 & 1965.5 \\
\hline L4 & 2 & 35.3 & 31.4 & 65.5 & 41.8 & 141.0 & 471.9 & 14.9 & 801.8 \\
\hline L4 & 3 & 5.7 & 3.2 & 3.6 & 37.3 & 29.2 & 561.6 & 42.9 & 683.4 \\
\hline $\mathrm{L} 4$ & 4 & 19.0 & 15.4 & 32.1 & 59.0 & 155.0 & 1038.9 & 36.8 & 1356.2 \\
\hline L4 & 5 & 25.3 & 38.6 & 92.7 & 75.3 & 276.6 & 1337.2 & 11.8 & 1857.5 \\
\hline $\mathrm{L} 4$ & 6 & 33.2 & 58.3 & 80.7 & 39.6 & 132.9 & 1983.8 & 25.3 & 2353.8 \\
\hline L4 & 8 & 124 & 21.0 & 31.0 & 15.6 & 553.5 & 2417.1 & 85.2 & 3135.7 \\
\hline L4 & 9 & 45 & 8.6 & 7.7 & 10.2 & 202.0 & 742.0 & 24.9 & 999.8 \\
\hline L.4 & 10 & 7.7 & 3.8 & 0.7 & 4.3 & 515.3 & 88.6 & 14.9 & 635.3 \\
\hline L4 & 11 & 7.0 & 5.2 & 5.7 & 24.6 & 345.8 & 948.7 & 147.4 & 1484.4 \\
\hline BON & 1 & 0.0 & 0.0 & 0.0 & 19.9 & 116.8 & 1720.5 & 0.0 & 1857.3 \\
\hline $\mathrm{BON}$ & 3 & 0.0 & 0.0 & 0.0 & 2.9 & 36.6 & 167.7 & 23.7 & 231.0 \\
\hline $\mathrm{BON}$ & 6 & 3.2 & 0.0 & 0.0 & 19.7 & 64.0 & 1040.7 & 21.5 & 1149.0 \\
\hline $\mathrm{BON}$ & 9 & 0.2 & 0.0 & 0.0 & 19.9 & 20.6 & 786.9 & 14.7 & 842.3 \\
\hline $\mathrm{BON}$ & 10 & 0.2 & 0.0 & 0.0 & 20.8 & 64.9 & 3346.2 & 59.4 & 3491.5 \\
\hline $\mathrm{BON}$ & 11 & 0.0 & 0.0 & 0.0 & 24.2 & 26.2 & 572.5 & 16.5 & 639.4 \\
\hline BON & 13 & 0.2 & 0.0 & 0.0 & 110.7 & 195.7 & 3500.3 & 126.8 & 3933.8 \\
\hline $\mathrm{BON}$ & 16 & 0.2 & 1.8 & 7.7 & 28.2 & 469.2 & 3539.6 & 15.8 & 4062.6 \\
\hline BON & 19 & 0.7 & 2.9 & 37.1 & 77.1 & 735.2 & 800.7 & 116.6 & 1770.3 \\
\hline
\end{tabular}


Table 4. Calanus finmarchicus. Biomasses of individual stages along the longitudinal sections from north to south (mg dry wt $\mathrm{m}^{-2}$ )

\begin{tabular}{|c|c|c|c|c|c|c|c|c|c|}
\hline Line & Stn & I & II & III & $\begin{array}{c}\text { Stage } \\
\text { IV }\end{array}$ & V & VI F & VI M & Total \\
\hline L5 & 27 & 15.6 & 5.4 & 5.2 & 5.7 & 0.0 & 9.3 & 1.1 & 42.3 \\
\hline L5 & 26 & 10.1 & 11.8 & 10.3 & 10.4 & 57.1 & 142.2 & 5.2 & 46.9 \\
\hline $\mathrm{L} 5$ & 24 & 6.1 & 6.8 & 13.3 & 119.6 & 550.3 & 3262.3 & 264.9 & 4223.3 \\
\hline L5 & 23 & 0.5 & 1.1 & 5.7 & 251.1 & 816.5 & 4381.2 & 831.9 & 6288.0 \\
\hline L5 & 20 & 7.2 & 9.7 & 8.4 & 14.0 & 148.7 & 789.9 & 303.1 & 1281.0 \\
\hline L5 & 18 & 8.1 & 16.7 & 12.7 & 90.2 & 1693.9 & 8754.1 & 431.4 & 11007.1 \\
\hline L5 & 16 & 3.4 & 4.1 & 12.0 & 18.8 & 412.2 & 1855.7 & 37.5 & 2343.6 \\
\hline L5 & 14 & 24.4 & 50.6 & 68.8 & 151.0 & 184.9 & 920.5 & 24.9 & 1425.0 \\
\hline L6 & 18 & 125.9 & 153.5 & 482.1 & 1019.5 & 967.5 & 756.9 & 0.0 & 3505.3 \\
\hline L6 & 17 & 57.9 & 55.8 & 86.3 & 241.4 & 1107.4 & 1215.9 & 0.0 & 2764.7 \\
\hline L6 & 16 & 5.0 & 83.6 & 2548.6 & 5348.1 & 4547.3 & 2121.2 & 0.0 & 14653.8 \\
\hline L6 & 15 & 7.0 & 31.2 & 194.4 & 942.0 & 784.2 & 1236.4 & 0.0 & 3195.2 \\
\hline L6 & 14 & 33.9 & 144.6 & 297.4 & 1653.6 & 779.2 & 4405.2 & 0.0 & 7314.0 \\
\hline L6 & 13 & 27.6 & 91.8 & 330.9 & 444.1 & 356.2 & 57.2 & 1045.5 & 2353.1 \\
\hline L6 & 12 & 65.1 & 103.5 & 360.5 & 640.7 & 561.4 & 4245.2 & 68.9 & 6045.3 \\
\hline L6 & 11 & 38.2 & 35.7 & 81.4 & 121.1 & 370.0 & 293.8 & 64.0 & 1004.1 \\
\hline L6 & 9 & 18.8 & 14.5 & 10.4 & 17.0 & 66.0 & 580.8 & 21.9 & 729.3 \\
\hline L6 & 8 & 13.3 & 6.3 & 7.5 & 32.3 & 90.4 & 558.7 & 51.1 & 759.6 \\
\hline L6 & 7 & 12.4 & 19.7 & 0.0 & 66.9 & 279.6 & 1352.2 & 9.3 & 1740.0 \\
\hline L6 & 5 & 2.3 & 2.7 & 5.7 & 5.2 & 515.7 & 680.9 & 76.6 & 1289.1 \\
\hline L6 & 4 & 12.9 & 12.2 & 14.7 & 17.6 & 301.5 & 1593.5 & 45.7 & 1998.1 \\
\hline L6 & 3 & 0.0 & 0.2 & 5.4 & 0.0 & 710.1 & 1606.2 & 99.0 & 2420.9 \\
\hline L6 & 2 & 0.0 & 0.2 & 0.2 & 3.8 & 1181.1 & 2992.7 & 124.8 & 4302.8 \\
\hline L6 & 1 & 13.6 & 16.5 & 6.8 & 20.1 & 497.9 & 2613.2 & 123.4 & 3291.5 \\
\hline
\end{tabular}

finmarchicus was by far the most abundant of the 3 Calanus spp. found in the region and was the only one which was reproductively active at this time, it is reasonable to assume that all of the calanoid nauplii collected would have been $C$. finmarchicus nauplii. Hauls using a $200 \mu \mathrm{m}$ mesh may have underestimated the abundance of nauplii, because of extrusion of the smaller stages through the net, but we suggest that our values are probably good estimates of relative abundance, because over all stations, while measured naupliar abundances were unrelated to measured abundances of Oithona spp. (a fairly ubiquitous and similar-sized, but unrelated organism; $\mathrm{p}>0.5$ ), they were highly correlated with those of $C$. finmarchicus CIs and CIIs ( $p<0.001$, in each case). Relative abundances of nauplii were not correlated with female abundances ( $\mathrm{p}>0.4$ ) nor with areal estimates of egg production rate $(p>0.05)$. The highest relative naupliar abundances occurred at stations L3 Stn 26, L2 Stn 1, L2 Stn 15 (124300, 149838 and $305552 \mathrm{~m}^{-2}$, respectively), which were all within the bloom zone (Fig. 10). Average relative naupliar abundances were higher in bloom and late/postbloom zones than in the early bloom zone. It should be noted that we did not inlude data on naupliar abundances on the Scotian Shelf, since at those stations there were probably other species of calanoid nauplii present.

\section{DISCUSSION}

\section{Phytoplankton bloom development in the Labrador Sea}

The pattern of bloom development in the Labrador Sea sampling area (late/post-bloom conditions in northern areas; bloom conditions at the middle latitutes; early bloom conditions in the southeast) was consistent with observations made during the 1963, Norwestlant surveys (ICNAF 1968), and with observations of surface chlorophyll concentrations made by satellite during 1998. For example, during the April Norwestlant I survey period, phytoplankton concentrations at $10 \mathrm{~m}$ were high along the west coast of Greenland north of $60^{\circ} \mathrm{N}$, but low to the south of Greenland and from there to Labrador, in the general area of our L3 line. During the late May-early June Norwestlant II 
Integrated chlorophyll concentration $\left(\mathrm{mg} \mathrm{m}^{-2}\right)$

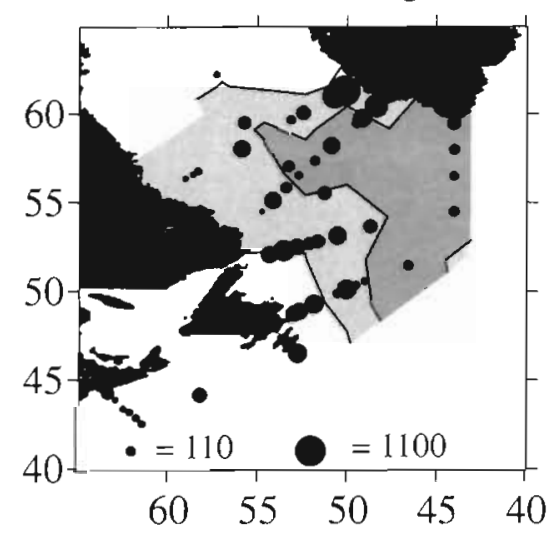

Egg production rate (Eggs $\left.\mathrm{m}^{-2} \mathrm{~d}^{-1}\right)$

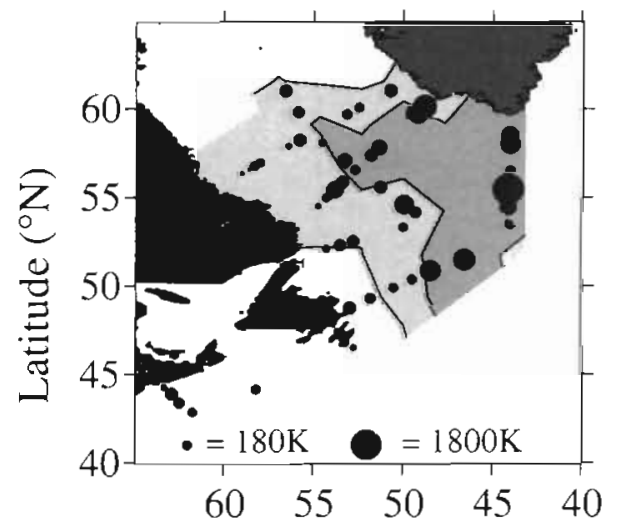

Relative abundance of nauplii (No. $\mathrm{m}^{-2}$ )

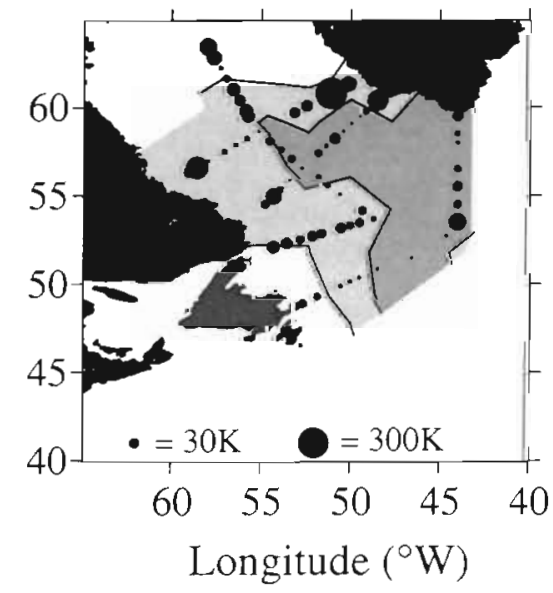

Fig. 10. Areas of the Labrador Sea designated as early bloom (dark grey), bloom (medium grey) and late/post-bloom (light grey) zones, on the basis of the 1 and $6 \mu \mathrm{M}$ contours of nearsurface nitrate concentration. The areas of the solid circles are proportional to: integrated chlorophyll concentration $\left(\mathrm{mg} \mathrm{m}^{-2}\right.$, upper panel); areal egg production rate (eggs $\mathrm{m}^{-2} \mathrm{~d}^{-1}$ ) and relative naupliar abundances (no. $\mathrm{m}^{-2}$ ) survey period, phytoplankton concentrations were lower than they had been in April north of $60^{\circ} \mathrm{N}$, and intermediate or high, but patchy, throughout the Labrador Sea and to the south of Greenland. Similarily, in early April 1998, observations of surface chlorophyll concentrations, compiled from the SeaWifs satellite images for bi-weekly intervals (L. Payzant \& H. Bishop pers. comm.) showed high values over the central Labrador Sea basin north of $60^{\circ} \mathrm{N}$ and east of $54^{\circ} \mathrm{W}$ (and from Flemish Cap and the Grand Bank southwest to Georges Bank) and low values to the south of Greenland. Thereafter there was a progression of the bloom southwards into the central Labrador Sea through May, with high values occurring south of Greenland in early June. Thus, it seems that early blooming in the north and east is a regular occurrence. One explanation for this might be the influence of locally melting ice in late winter. In general, in March ice covers the entire Labrador Shelf and the deep water north of a line between ca $60^{\circ} \mathrm{N}, 60^{\circ} \mathrm{W}$ and $66^{\circ} \mathrm{N}, 55^{\circ} \mathrm{W}$ (Drinkwater \& Mountain 1997). Ice-melt starts in earnest in April, and the prevailing winds are northwesterly with the potential to advect fresh water towards the southeast, causing density stratification that allows the bloom to develop. In fact, in 1998 there was a slight 'greening' in the northern regions in the satellite image for late March, implying that the melt may sometimes start earlier than April. The connection between bloom development and melting ice has been recognised in the Barents Sea (Rey \& Loeng 1985), the Greenland Sea (Spies 1987) and other seasonally icecovered areas (Smith \& Nelson 1985).

It is generally accepted that in order for phytoplankton to bloom in spring following deep winter mixing, stratification of the water column is required via the formation of either a pycnocline (as discussed above) or a thermocline (caused by solar warming of the surface layers). Exceptions to this pattern, however, are common in boreal, temperate and polar regions (Colebrook 1979, Townsend et al. 1992, Wassmann et al. 1996), as well as in Norwegian fjords (Wassmann 1991. Eilertsen 1993, Wassmann et al. 1996). Townsend et al. (1992) suggested that for temperate ocean areas the increasing light penetration in spring and the clarity of the post-winter water are sufficient conditions to allow phytoplankton to bloom, if winds are light and vertical mixing is not deep. In contrast, if wind strengths are high and vertical mixing extends to depths below the critical depth, a bloom should not be expected. During our sampling in the Labrador Sea there was little thermal stratification of the water column on any of the lines, with the possible exception of the Labrador Shelf area of the L4 line, where solar warming may have had an influence. There was, however, only slight evidence of elevated chlorophyll concentrations there and these 
Table 5. Characteristics of zones designated as 'early bloom', 'bloom' and 'late/post-bloom' zones in the Labrador Sea in May 1997. Values are shown as averages \pm SD and the number of stations contributing is shown in brackets below. EPR: egg production rate; fem.: female

\begin{tabular}{|c|c|c|c|c|c|c|}
\hline $\begin{array}{l}\text { Near-surface } \\
\text { nitrate conc. } \\
\qquad(\mu \mathrm{M})\end{array}$ & $\begin{array}{l}\text { Integrated } \\
\text { chl. conc. } \\
\left(\mathrm{mg} \mathrm{m}^{-2}\right)\end{array}$ & $\begin{array}{c}\text { Female } \\
\text { EPR } \\
\text { (eggs fem. } \\
\text { (eg } \mathrm{d}^{-1} \text { ) }\end{array}$ & $\begin{array}{c}\text { Female } \\
\text { abundance } \\
\text { (fem. } \mathrm{m}^{-2} \text { ) }\end{array}$ & $\begin{array}{c}\text { Areal } \\
\text { EPR } \\
\text { (eggs } \mathrm{m}^{-2} \mathrm{~d}^{-1} \text { ) }\end{array}$ & $\begin{array}{l}\text { Relative naupliar } \\
\text { abundance } \\
\left(\text { no. } \mathrm{m}^{-2} \text { ) }\right.\end{array}$ & $\begin{array}{c}\text { Male } \\
\text { abundance } \\
\text { (male } \mathrm{m}^{-2} \text { ) }\end{array}$ \\
\hline \multicolumn{7}{|l|}{ Early bloom zone } \\
\hline $\begin{array}{c}8.3 \pm 2.6^{\circ} \\
(11)\end{array}$ & $\begin{array}{c}149 \pm 100^{\circ} \\
(11)\end{array}$ & $\begin{array}{c}71.3 \pm 15.8^{a} \\
(16)\end{array}$ & $\begin{array}{c}6617 \pm 6034 \\
(24)\end{array}$ & $\begin{array}{c}548491 \pm 441367^{\mathrm{a}} \\
(16)\end{array}$ & $\begin{array}{c}10150 \pm 17547^{\circ} \\
(24)\end{array}$ & $\begin{array}{c}542 \pm 649^{a} \\
(24)\end{array}$ \\
\hline \multicolumn{7}{|l|}{ Bloom zone } \\
\hline $\begin{array}{c}3.7 \pm 3.0^{\circ} \\
(25)\end{array}$ & $\begin{array}{c}304 \pm 282 \\
(25)\end{array}$ & $\begin{array}{c}47.3 \pm 22.4 \\
(29)\end{array}$ & $\begin{array}{c}4363 \pm 5302 \\
(44)\end{array}$ & $\begin{array}{c}186750 \pm 145787 \\
(29)\end{array}$ & $\begin{array}{c}33642 \pm 51828 \\
(44)\end{array}$ & $\begin{array}{c}151 \pm 178 \\
(44)\end{array}$ \\
\hline \multicolumn{7}{|l|}{ Late/post-bloom zone } \\
\hline $\begin{array}{c}0.4 \pm 0.9^{\circ} \\
(7)\end{array}$ & $\begin{array}{c}296 \pm 137 \\
(7)\end{array}$ & $\begin{array}{c}25.9 \pm 21.1 \\
(5)\end{array}$ & $\begin{array}{c}3060 \pm 1750 \\
(7)\end{array}$ & $\begin{array}{c}94543 \pm 109995 \\
\text { (5) }\end{array}$ & $\begin{array}{c}31717 \pm 31900 \\
(7)\end{array}$ & $\begin{array}{c}40 \pm 52 \\
(7)\end{array}$ \\
\hline
\end{tabular}

only in the subsurface layers, since surface nitrate concentrations had already been depleted (Figs. 3 \& 6), probably because of prior surface blooming in association with density stratification caused by melting ice. Elsewhere, at stations near the shelf break of the Greenland (L2) and Labrador (L3, L4) shelves, where there was weak density stratification, there tended to be areas of enhanced phytoplankton concentration. Intense blooms also occurred, however, in some localised areas of the central Labrador Sea which were essentially unstratified (e.g. L2 and L3 lines), but not in others, and chlorophyll concentrations were relatively low in the unstratified waters to the south of Greenland (L5). The phytoplankton species composition, which was examined along the L3 line only, was similar to that reported for other boreal areas in spring (e.g. Spies 1987, Wassmann et al. 1990): Phaeocystis pouchetii was the most abundant phytoplankton species at all bloom stations, with diatoms (e.g. Chaetoceros and Thalassiosira spp.) quite abundant at bloom stations near the Greenland shelf and jointly more abundant than $P$. pouchetii at L3 Stn 22 (W. K. W. Li unpubl. data). One question that arises from our observations is why blooms should have occurred in some unstratified areas and not in others. We suggest that this may have been caused by differences in the extent of vertical mixing. During our cruise to the Labrador Sea, average daily wind speeds were $>20$ knots on 4 of the $8 \mathrm{~d}$ it took to sample the BON and L5 lines, and $<15$ knots on only 2. By contrast, during the following $18 \mathrm{~d}$ spent sampling the L3, L2, L6 and L4 lines, average daily wind speeds were $>20$ knots on only $2 \mathrm{~d}$ and $<15$ knots on $11 \mathrm{~d}$. Instantaneous shipboard observations of wind speed cannot be used to hindcast the likelihood of encoutering of blooms at particular stations, since the past history and duration of local mixing events are unknown. They do suggest, however, that vertical mixing was generally more extensive on the BON and L5 lines than on lines farther north, which is consistent with our observation that intense blooms had not become established in this area.

Another factor, which might influence the dynamics of the spring bloom, is the timing of the return to the surface layers of populations of mesozooplankton, such as Calanus finmarchicus, which overwinter at depth (Bathmann et al. 1990, Wassmann et al. 1996). If their concentrations are high and if their return precedes the initiation of the bloom, then their grazing might be sufficient to delay it or depress its intensity. To examine this possibility we estimated potential daily carbon requirements for the copepods and phytoplankton growth rates using some very simple assumptions. To estimate copepod carbon demands at each station, we took the sum of the dry weights of all 3 Calanus spp. (C. finmarchicus, C. glacialis and C. hyperboreus), which constituted $>80 \%$ of the herbivorous zooplankton biomass (Head unpubl. data) and assumed a carbon content of $50 \%$ and a carbon specific requirement of $30 \% \mathrm{~d}^{-1}$. To estimate phytoplankton growth rates we either used the integrated chlorophyll concentration and assumed a carbon:chlorophyll ratio of 50 and a doubling time of $1 \mathrm{~d}^{-1}$ or a maximum value of $2.3 \mathrm{~g} \mathrm{C}$ $\mathrm{m}^{-2} \mathrm{~d}^{-1}$ (Longhurst 1995), if our calculated value was higher than this. Data was available for 8 stations in the early bloom zone: at 1 (L3 Stn 21), copepod demand for carbon was $<10 \%$ of phytoplankton production; at 4 (BON Stn 11, L3 Stn 8, L5 Stn 16, L5 Stn 20 ), it was between 10 and $22 \%$; and at 3 (BON Stn 16 , L3 Stn 22, L5 Stn 23), it was between 40 and $50 \%$. Thus, although copepod grazing might have been affecting bloom development at some early bloom stations, it was probably not important at others. 


\section{Calanus finmarchicus maturation and spawning in relation to the phytoplankton bloom}

The highest rates of egg-laying by female Calanus finmarchicus occurred in the early bloom zone, suggesting that even though chlorophyll concentrations were relatively low, egg production was not limited by food. In fact, however, at most early bloom stations integrated chlorophyll concentrations exceeded $79 \mathrm{mg}$ $\mathrm{m}^{-2}$, which appears to be the concentration below which C. finmarchicus egg production rates becomes food limited in the western Atlantic (Campbell 1998, Campbell \& Head 2000). This and other observations of egg-laying by $C$. finmarchicus before the development of the spring bloom (Diel \& Tande 1992, Gislasson \& Astthorsson 1996) do not contradict the idea that females need to feed to produce eggs (Marshall \& Orr 1952, Plourde \& Runge 1993, Hirche et al. 1997), but rather show that relatively low food concentrations, which may occur before the bloom becomes established, are sufficient to allow females to produce eggs at maximal rates.

Egg-laying by Calanus finmarchicus was occurring before the bloom had become established in some areas, but the products of reproduction were more abundant in areas showing bloom (nauplii) or late/postbloom conditions (nauplii and CI-CIIIs). In fact, at the northern stations of the L6 line, stage distributions suggest that even many of the later stage copepodites (CIVs and CVs) were from the G1 (current year's) generation (Table 2). Also, at L6 Stns 16 and 18, where egg production rates were zero or near zero, most of the females were reproductively immature (Campbell 1998), probably because they also belonged to the G1 generation. At stations slightly farther south (L6 Stns 12 and 14), where egg production rates and the proportion of females with mature gonads were also relatively low, female populations probably consisted of mixtures of the G1 and G0 (overwintered) generations

According to Matthews (1968), diapausing Calanus finmarchicus emerge at the same time throughout our study area. Thus, one question that arises is why there were no or few Go females at the northerly stations: if Go females were abundant farther south, they should also have been present in the north. One possible explanation is that although egg production rates in mature females were not generally limited by food, perhaps rates of development from immature to mature egg-laying females were more affected. Thus, if there had been an intense early bloom (March/April) in the northeast Labrador Sea in 1997 (as in other years), females there would have matured and started producing eggs earlier than those farther south, so that they would have become spent and died by the sampling time (early June) after a ca 2 mo spawning period. In other areas gonad maturation would have been slower and the onset of egg production would have been delayed. Females had apparently attained maturity in areas where the bloom had not yet become established by mid-May, however, since egg production rates in the early bloom zone were very high. Thus, once mature, it appears that females can produce eggs at maximal rates, more-or-less independent of in situ food concentration, presumably until they become spent and die. The scheme that we propose is similar to that discussed by Diel \& Tande (1992), who compared spawning times of $C$. finmarchicus in Norwegian fjords (early) and in nearby open ocean areas (later) and who concluded, as we have, that temperature differences could not account for differences in maturation rates, and that food supply was also important. The link between female maturation and bloom development has been noted elsewhere (e.g. Marshall \& Orr 1952, Tande et al. 1985, Plourde \& Runge 1993), although our explanation of the observation that maximal egg production rates may precede the establishment of a delayed bloom is somewhat novel.

Abundances of females did not vary between zones, but abundances of males in the near-surface layers were highest in the early bloom zone and lower in the other 2 zones (Table 5): indeed, males were often absent from stations in the late/post-bloom zone. Previous studies have suggested that adult males tend to appear in the population earlier than females, that they fertilize immature females, possibly while still at overwintering depths (e.g. Tande \& Hopkins 1981, Miller et al. 1991), and that they do not live as long as females (Hirche 1996). It is difficult to reconcile these behaviours with our observations, if arousal from diapause was more-or-less synchronous over the study area. Instead, our data suggest that, as for females, maturation of overwintered males was delayed at southern latitudes.

Another possible explanation for our observations of adult abundances is that the arousal of Calanus finmarchicus populations was not synchronous everywhere, but occurred earlier at more northerly latititudes. This seems unlikely, however, since there appears to be a reasonably high degree of synchrony in arousal times from 40 to $70^{\circ} \mathrm{N}$ (Miller et al. 1991) and the suggested triggers (photo-period or internal clock; Hirch 1996) would not lead us to predict early arousal in the north. Yet another suggestion is that adult $C$. finmarchicus to the south of Greenland and in the central Labrador Sea (i.e. early bloom zones) belonged to the G1 generation, derived from members of a population that appear to have an early (January) start to their upward migration in an area south of Newfoundland (Planque et al. 1997). This too seems unlikely: firstly, because the abundances of 
young stages were generally lower than those of the adults at these stations; and secondly, because on Flemish Cap and to the southwest of Iceland, it is clear that it is the GO population which spawns in April and/or May (Anderson 1990, Gislason \& Astthorsson 1995).

Overall, our observations suggest that following arousal from diapause, maturation rates for both male and female Calanus finmarchicus are low before the development of the spring bloom, but accelerate as phytoplankton levels rise. This scheme appears to provide overwintered $C$. finmarchicus with the ability to respond rapidly to early intense blooms, such as sometimes occur in several areas of its distribution. In general, however, reproduction should be maximal during the bloom, but if the bloom is unusually late or of low intensity in a given year and area, then reproduction of the Go generation will be delayed and may occur under conditions unfavourable to the development of the new G1 generation (see below).

\section{Development of the G1 generation}

The pattern of copepodite distribution that we observed (CI-IIIs dominant in the north, adults farther south) is consistent with previous observations for the region at this time of year. The Norwestlant II (MayJune) data show high abundances of CI-IIIs in the north, and much lower total abundances, with higher proportions of adults, at stations to the south of Greenland. In Davis Strait (ca $70^{\circ} \mathrm{N}$ ), Huntley et al. (1983) found concentrations of CI-III Calanus finmarchicus increased between April-May and June samplings. In April-May, adults were dominant in western Davis Strait (ca 60 to $68^{\circ} \mathrm{N}$ ), but by June these had been displaced by CI-IIIs. Matthews (1968) interpreted the Norwestlant data as showing progressively decreasing rates of development from south to north, which he attributed to differences in temperature. Close examination of the original data does not support this view for the progression between April and May-June sampling periods, however, and his analysis may also have been confounded by the fact that $C$. finmarchicus was not distinguished from C. glacialis in samples from the April survey.

Our observations of Calanus finmarchicus relative naupliar abundances and copepodite abundances and stage distributions strongly suggest that development was linked to the progress of the bloom, so that the G1 generation was more advanced in the north. Furthermore, even though egg production rates were very high in our early bloom zone, few nauplii were found. Although it is conceivable that their scarcity was simply due to timing (i.e. egg-laying had started only within the last 1 to $2 \mathrm{wk}$ ), Marshall \& Orr (1955) noted that in Loch Striven most $C$. finmarchicus eggs laid before the bloom failed to develop into a new generation and they suggested that this might have been because the smaller, less mobile early life stages need relatively high concentrations of suitable (e.g. small) food items. The small size and lack of mobility of eggs and early stages also suggest another factor that might contribute to their demise: namely, predation. One potential predator might be the female $C$. finmarchicus themselves, which are known to eat their own eggs under experimental conditions (Cabal et al. 1997). If we assume filtration rates ca $2 \mathrm{ml} \mathrm{female}{ }^{-1} \mathrm{~h}^{-1}$, then even where the females were most abundant (ca $23000 \mathrm{~m}^{-2}$ at L5 Stn 18), and if they had been concentrated over a depth range of only $5 \mathrm{~m}$, they would only have filtered ca $20 \%$ of that $5 \mathrm{~m}$ water column in a $24 \mathrm{~h}$ period. On the basis of this calculation it seems unlikely that cannibalism would have been very important in situ. Another potential predator might have been the carnivorous copepod Euchaeta norvegica. This species is very abundant throughout the deep water in the entire sampling area and appears to reproduce in January or February (Head \& Harris unpubl. data). By May, the dominant stages are IIs, IIIs and IVs, for which $C$. finmarchicus eggs and nauplii would probably be suitable prey. Larval redfish (Sebastes spp.) might also have been important predators: they are known to consume $C$. finmarchicus eggs in large numbers (Runge $\&$ de Lafontaine 1996). At this time of year, larval redfish occur in the deep waters south and east of Greenland and they are very abundant in the Irminger Sea (ICNAF 1968), although we did not see any in our vertical nets tows. In the presence of high phytoplankton concentrations cannibalism on eggs by females would probably be reduced, since they would easily be able to fulfill their nutritional requirements and E. norvegica and fish larvae may be less able to capture their prey: for the latter, which are visual predators, this might be caused by a reduction in under water light intensity.

Once the eggs had developed into the larger nauplii, which would have been sampled relatively efficiently with our $200 \mu \mathrm{m}$ net, it appears that there was a reduction in the mortality and it became more regular, since naupliar abundances were well correlated with the somewhat lower abundances of CIs and CIIs. In addition, it appears that high phytoplankton levels per se may not have been important for further development, perhaps because a greater selection of larger food items became available: for example, phytoplankton concentrations were low at the northern stations of the L6 line, but ciliate microzooplankton were very abundant. One might also anticipate that at this stage of development the effect 
of temperature on growth rate might become more important, which would tend to bring the northern advanced population into synchrony with the southern retarded population as the summer progresses, as seen during the Norwestlant II and III surveys (Matthews 1968).

\section{Implications for recruitment in Calanus finmarchicus in the Labrador Sea}

In the Labrador Sea it is possible that the timing of the spring bloom may have an important influence of the level of recruitment to the new year's G1 generation of Calanus finmarchicus, since if the bloom is late and eggs are laid before high phytoplankton concentrations prevail, many may not survive. Elsewhere, where there are multiple generations, recruitment to G2 and subsequent generations may be able to make up for a poor G1 recruitment, but in the Labrador Sea, low temperatures and a short growth season probably preclude such a compensatory mechanism.

Acknowledgements. The authors would like to thank Jeff Anning and Anthony Isenor for supplying data and expert technical support, and K. F. Drinkwater, W. K. W. Li and the 4 anonymous reviewers for commenting on earlier versions of the text. Financial support was provided by the Canadian Program of Energy Research and Development (PERD), the Ocean Climate Program (OCP) and NSERC, under the GLOBEC-Canada program.

\section{LITERATURE CITED}

Anderson JT (1990) Seasonal development of invertebrate zooplankton on Flemish Cap. Mar Ecol Prog Ser 67: $127-140$

Bathmann UV, Noji TT, von Bodungen B (1990) Copepod grazing potential in late winter in the Norwegian Sea-a factor in the control of spring phytoplankton growth? Mar Ecol Prog Ser 60:225-233

Cabal J, Harris LR, Head EJH (1997) Egg production rates of Calanus finmarchicus in the northwest Atlantic (Labrador Sea). Can J Fish Aquat Sci 54:1270-1279

Campbell RW (1998) Reproduction of Calanus finmarchicus in the western North Atlantic: fecundity and hatching success. Master thesis, Dalhousie Univ

Campbell RW, Head EJH (2000) Egg prodcution rates of Calanus finmarchicus in the western North Atlantic: effect of gonad maturity, female size, chlorophyll concentration and temperature. Can J Fish Aquat Sci (in press)

Colebrook JM (1979) Continuous plankton records: seasonal cycles of phytoplankton and copepods in the North Atlantic Ocean and the North Sea. J Plankton Res 4: $435-462$

Diel S, Tande K (1992) Does the spawning of Calanus finmarchicus in high latitudes follow a reproducible pattern? Mar Biol i13:21-31

Drinkwater KF, Mountain DG (1997) Climate and oceanography, Chap 1. In: Boreman J, Nakashima BS, Wilson JA,
Kendall RL (eds) Northwest Atlantic groundfish: a perspective on a fishery collapse. American Fisheries Society, Bethesda, MD, p 3-25

Durbin EG, Runge JA, Campbell RG, Garrahan PR, Casas MC, Plourde S (1997) Late fall-early winter recruitment of Calanus finmarchicus on Georges Bank. Mar Ecol Prog Ser 151:103-114

Eilertsen HC (1993) Spring blooms and stratification. Nature 363:24

Gaard E (1996) Life cycle, abundance and transport of Calanus finmarchicus in Faroese waters. Ophelia 44: $59-70$

Gislason A, Astthorsson OS (1995) Seasonal cycle of zooplankton southwest of Iceland. J Plankton Res 17:1959-1976

Gislason A, Astthorsson OS (1996) Seasonal development of Calanus finmarchicus along an inshore-offshore gradient southwest of Iceland. Ophelia 44:71-84

Gislason A, Astthorsson OS (1998) Seasonal variations in biomass, abundance and composition of zooplankton in the subarctic waters north of Iceland. Polar Biol 20:85-94

Grainger EH (1963) Copepods of the genus Calanus as indicators of Eastern Canadian waters. In: Dunbar MJ (ed) Marine distributions. R Soc Can, Special Publ No 5, Univ Toronto Press

Hirche HJ (1996) The reproductive biology of the marine copepod, Calanus finmarchicus - a review. Ophelia 44: 111-128

Hirche HJ, Meyer U, Niehoff B (1997) Egg production of Calanus finmarchicus: effect of temperature, food and season. Mar Biol 127:609-620

Holm-Hansen O, Lorenzen CJ, Holmes RW, Strickland JDH (1965) Fluorimetric determinations of chlorophyll. J Cons Int Explor Mer 30:3-15

Huntley M, Strong KW, Dengler AT (1983) Dynamics and community structure of zooplankton in the Davis Strait and Northern Labrador Sea. Arctic 36:143-161

ICNAF Special Report No 7 (1968) Enviromental SurveysNorwestlant $1-3,1963$. Issued from the Headquaterters of the Commission, Dartmouth, NS

Kielhorn WV (1952) The biology of the surface zone zooplankton of a boreo-arctic Atlantic Ocean area. J Fish Res Board Can 9:223-264

Longhurst A (1995) Seasonal cycles of pelagic production and consumption. Prog Oceanogr 36:77-167

Longhurst A, Williams R (1992) Carbon flux by seasonal migrant copepods is a small number J Plankton Res 14: 1495-1509

Marshall SM, Orr AP (1952) On the biology of Calanus finmarchicus VII Factors affecting egg production. J Mar Biol Assoc UK 30:527-547

Marshall SM, Orr AP (1955) The biology or a marine copepod Calanus finmarchicus (Gunnerus). Oliver and Boyd, Edinburgh

Matthews JBL (1968) On the acclimatization of Calanus finmarchicus (Crustacea, Copepoda) to different tempera ture conditions in the north Atlantic. Sarsia 34:371-382

McLaren IA, Corkett CJ (1986) Life cycles and production of two copepods on the Scotian Shelf, eastern Canada Syllogeus. Nat Mus Can 58:362-368

Miller CB, Cowles TJ, Wiebe PH, Copley NJ, Grigg H (1991) Phenology in Calanus finmarchicus; hypotheses about control mechanisms. Mar Ecol Prog Ser 72:79-91

Planque B, Hays GC, Ibanez F, Gamble JC (1997) Large scale spatial variations in the seasonal abundance of Calanus finmarchicus. Deep-Sea Res I 44:315-326

Plourde S, Runge JA (1993) Reproduction of the planktonic copepod Calanus finmarchicus in the lower St. Lawrence 
Estuary: relation to the cycle of phytoplankton production and evidence for a Calanus pump. Mar Ecol Prog Ser 102: 217-227

Rey F, Loeng $H$ (1985) The influence of ice and hydrographic conditions on the development of phytoplankton in the Barents Sea. In: Gray J, Christiansen M (eds) Marine biology of polar regions and effect of stress on marine organisms. Wiley, Chichester, p 49-63

Runge JA, de Lafontaine $Y$ (1996) Chararterization of the pelagic ecosystem in surface waters of the northern Gulf of St. Lawrence in early summer: the larval redfish-Calanus-microplankton interaction. Fish Oceanogr 5:21-37

Runge JA, Plourde S (1996) Fecundity characteristics of Calanus finmarchicus in coastal waters of eastern Canada. Ophelia 44:171-187

Smith WO, Nelson DM (1985) Phytoplankton bloom produced by a receding ice edge in the Ross Sea: coherence with the density field. Science 227:163-166

Spies A (1987) Phytoplankton in the marginal ice zone of the Greenland Sea during summer, 1984. Polar Biol 7: 195-205

Tande KS, Hopkins CCE (1981) Ecological investigations

Editorial responsibility: Otto Kinne (Editor),

Oldendorf/Luhe, Germany of the zooplankton community of Balsfjorden, Northern Norway: the genital system in Calanus finmarchicus and the role of gonad development in overwintering strategy. Mar Biol 63:159-164

Tande KS, Hassel A, Slagstad D (1985) Gonad maturation and possible life cycle strategies in Calanus finmarchicus and Calanus glacialis in the northwestern part of the Barents Sea. In: Gray J, Christiansen $M$ (eds) Marine biology of polar regions and effect of stress on marine organisms. Wiley, Chichester, p 141-155

Townsend DW, Keller MD, Sieracki ME, Ackelson SG (1992) Spring phytoplankton blooms in the absence of vertical water column stratification. Nature 360:59-62

Wassmann P (1991) Dynamics of primary production and sedimentation in shallow fjords and polls of western Norway. Oceanogr Mar Biol Annu Rev 29:87-154

Wassmann P, Vernet M, Mitchell BG. Rey F (1990) Mass sedimentation of Phaeocystis pouchetii in the Barents Sea. Mar Ecol Prog Ser 66:183-195

Wassmann P, Andreassen I, Reigstad M, Slagstad D (1996) Pelagic-benthic coupling in the Nordic Seas: the role of episodic events. PSZN I: Mar Ecol 17:447-471

Submitted: March 24, 1999; Accepted: October 15, 1999 Proofs received from author(s): February 9, 2000 